\title{
The sources of long-term economic growth in Indonesia, 1880-2008
}

\author{
Pierre van der Eng ${ }^{* 1}$ \\ School of Management, Marketing \& International Business, College of Business and Economics, The Australian National University, Canberra, ACT 0200, Australia
}

\section{A R T I C L E I N F O}

\section{Article history:}

Received 1 November 2008

Available online 10 November 2009

\section{Keywords:}

Economic growth

Growth accounting

Factor accumulation

Productivity

Indonesia

\begin{abstract}
A B S T R A C T
This paper presents new time series estimates of GDP, capital stock and education-adjusted employment, and uses a growth accounting approach to analyze GDP growth during 18802008. The growth of capital stock, employment and educational attainment explained almost all of GDP growth. During key growth periods 1900-29 and 1975-97, Total Factor Productivity (TFP) growth was on balance negative. TFP growth was substantial during some sub-periods, particularly 1933-41, 1951-61, 1967-74 and 2000-08. Each followed a major economic downturn that slowed capital stock growth and required a more efficient use of productive resources, supported by changes in economic policy that enhanced productivity and efficiency.
\end{abstract}

(c) 2009 Elsevier Inc. All rights reserved.

\section{Introduction}

The broad dimensions of growth and structural change in Indonesia have been established in other publications (Van der Eng, 1992, 2002a). This paper builds on those results in order to outline possibilities for further research and discussion about Indonesia's growth experience. In particular, this paper initiates discussion about the contribution of Total Factor Productivity (TFP) growth to Indonesia's long-term economic growth. It presents new time series estimates of GDP, and tentatively explores and employs the data available to gauge long-term changes in capital stock, education-adjusted employment, and factor income shares. Some of these data are tentative, but offer an opportunity to explore the feasibility of growth accounting analysis. After accounting for the contribution of conventional factor inputs to GDP growth, the paper identifies the contribution of TFP.

Identification of the contribution of TFP allows an elaboration of Indonesia's long-term growth experience in the context of literature on the sources of long-term economic growth. In comparison, the data availability for Indonesia allows only a growth accounting approach that yields relatively crude TFP estimates. Without the refinement that was possible for other countries (see e.g. Abramovitz and David, 2001; Prados and Rosés, 2007), these cannot necessarily be taken as indications of the contribution made by technological change to long-term economic growth. Summarizing the historical growth accounting literature in particular for the UK, US and other Western countries, Crafts (2004) found consensus that TFP growth since the late 18th century has actually been quite modest. These findings underline the 'Solow Productivity Paradox', as they contrast sharply with notable evidence of technological change and its impact in these countries, e.g. in the form of steam power in the early 19th century and information technology in the late 20th. The answer to the paradox may lie in the embodiment of new technology in measures of capital stock.

The TFP estimates presented in this study will allow reflection on the results of multi-country growth studies that employed similar crude estimates. In the Asian context, a large part of the literature on the economics of macroeconomic growth is dominated by discussion about the degree to which TFP growth explains the 'Asian economic miracle' of high eco-

\footnotetext{
* Fax: +61 261258796.

E-mail address: pierre.vandereng@anu.edu.au

1 The author like to thank Howard Dick and Daan Marks, as well as participants in the conference Economic Change around the Indian Ocean in Venice (Italy) in July 2008, for their comments on previous versions of this paper.
} 
nomic growth since the 1960s. Young (1994) argued, on the basis of a 4-country study, that this 'miracle' was more the result of the mobilization of factors of production (labor and capital) than productivity growth - i.e. 'perspiration' rather than 'inspiration', as Krugman (1994) summarized the findings, initiating a series of studies that often used readily available multi-country data sets in order to estimate TFP growth, extending beyond Asia to cover different parts of the world. ${ }^{2}$ The multicountry studies that estimated TFP growth all found different, sometimes contradictory results. One of the reasons was that they had to make rather crude estimates of capital input on the basis of available national accounts data.

As a major Asian country, Indonesia has, of course, featured in the multi-country studies referred to above. Most found positive TFP growth, albeit to varying degrees (see Section 4). However, there are no reasons to regard the results of these studies as conclusive, as they failed to consider explicitly the quality and availability of Indonesian statistical data. Close scrutiny of the data from these multi-country studies also reveals inexplicable discrepancies with the original data produced at Statistics Indonesia (Badan Pusat Statistik, BPS), Indonesia's statistical agency, and its predecessors. Moreover, studies using multi-country data sets took national accounts data for granted. They did take account of revisions in these data over time, and their capital stock estimates often depended on rough assumptions, such as depreciation or lifetime of different categories of productive assets. Consequently, estimates of gross fixed capital formation and capital stock, for example, deviate significantly from estimates that take close account of the idiosyncrasies in Indonesia's statistical data and the composition of investment and capital stock (Van der Eng, 2009).

Indonesia's long-term economic growth has been the subject of several studies (e.g. Booth, 1998; Dick et al., 2002) and its growth experience in recent decades has undergone even closer scrutiny (e.g. Hill, 1999). However, these studies did not employ growth accounting as a tool of analysis and focused on the ultimate reasons for Indonesia's development in terms of changes in institutions and economic policies conducive to economic growth. Consequently, the proximate causes remain unclear, even though they underlie the country's economic growth experience and offer pointers to the periodization of the long-term growth experience as well as the relative relevance of ultimate explanations.

This paper seeks to resolve these inconsistent findings in the literature. It follows an approach used by Sigit (2004), but enhances it by using new long-term estimates of GDP in 2000 prices, new long-term estimates of capital stock in Indonesia in 2000 constant prices, estimates of the share of labor income, new estimates of education-adjusted employment, and an extension of the timeframe of analysis. The next section outlines the methodology and data used in the paper, while Section 3 discusses the data. Section 4 estimates the 'proximate' sources of economic growth in Indonesia. Section 5 concludes.

\section{Methodology of estimating TFP}

This paper uses a simple, direct accounting method to estimate the contribution of TFP growth to economic growth. The production function in Eq. (1) indicates that output during a given year is a function of the productive employment of the total stocks of capital and labor.

$$
Q_{t}=A_{t} f\left(K_{t}, L_{t}\right)
$$

Here, $Q_{t}=$ real output, $K_{t}=$ capital stock and $L_{t}=$ employment in year $t$, and $A_{t}$ is the efficiency term. Differentiating with respect to time yields Eq. (2).

$$
\frac{d Q}{d t}=\frac{d A}{d t} f\left(K_{t}, L_{t}\right)+A_{t} \frac{\partial f}{\partial K} \frac{d K}{d t}+A_{t} \frac{\partial f}{\partial L} \frac{d L}{d t}
$$

Dividing both sides by $Q_{t}$ yields Eq. (3).

$$
\frac{d Q}{d t} / Q_{t}=\frac{d A}{d t} / A_{t}+\frac{\partial f}{\partial K} \frac{d K}{d t} / f\left(K_{t}, L_{t}\right)+\frac{\partial f}{\partial L} \frac{d L}{d t} / f\left(K_{t}, L_{t}\right)
$$

Replacing the marginal productivities by factor prices then gives Eq. (4).

$$
g_{t}^{Q}=g_{t}^{\mathrm{TFP}}+\left(r K_{t} / Q_{t}\right) g_{t}^{K}+\left(w L_{t} / Q_{t}\right) g_{t}^{L}=g_{t}^{\mathrm{TFP}}+s_{k} g_{t}^{K}+s_{l} g_{t}^{L}
$$

Here, $g_{t}^{Q}, g_{t}^{\text {TFP }}, g_{t}^{K}$ and $g_{t}^{L}$ are the annual growth rates of output, TFP, capital and employment, respectively, $r=$ per unit service price of capital (interest) and $w=$ per unit service price of labor (wage rate), and $s_{k}$ and $s_{l}$ are the shares of income from capital and labor in national income respectively. Assuming constant returns to scale, or perfect elasticity of substitution between capital and labor, yields Eq. (5):

$$
s_{k}+s_{l}=1 \text { or } s_{k}=1-s_{l}
$$

Any effort to incorporate a measure of quality changes in the stock of capital goods, akin to e.g. Maddison (1987: 663664 ), is arbitrary, particularly given the paucity of detailed long-term investment data for Indonesia. However, it is possible to incorporate a measure of quality changes in the stock of employment by adjusting it for educational attainment in a way shown by Eq. (6).

\footnotetext{
${ }^{2}$ See e.g. Baier et al. (2006: 45), who concluded that TFP growth contributed only $14 \%$ to the growth of output per worker throughout the 20 th century, but $-37 \%$ in Indonesia. Other studies, such as Chen (1997), Felipe (1999) and Weerasinghe and Fane (2005), offer critical discussions of the results of these multicountry studies for Asian countries.
} 


$$
L_{t}^{*}=L_{t} e^{\alpha Y_{t}}
$$

Here, $L_{t}^{*}=$ education-adjusted employment, $L_{t}=$ number of gainfully employed, $\alpha$ = the elasticity of output for each additional year of education and $Y_{t}=$ the number of years of education per person employed. Substituting $L_{t}$ for $L_{t}^{*}$ in Eq. (1) and differentiating with respect to time yields a modified Eq. (4). Insertion of Eq. (5) into the modified Eq. (4) yields Eq. (7).

$$
g_{t}^{\mathrm{TFP}}=g_{t}^{Q}-\left(1-s_{l}\right) g_{t}^{K}-s_{l} g_{t}^{L^{*}}
$$

Thus, the key data required to estimate the contribution of TFP to economic growth are annual data on GDP and capital stock in constant prices, education-adjusted employment, and the labor income share in GDP. Since this paper is concerned with the national economy of Indonesia, it uses nation-wide data.

\section{Estimation of output and inputs}

\subsection{Output data}

Indonesia's official national accounts data have undergone at least six major revisions since the 1950s. These have in part been due to the adoption of new or improved estimation procedures, improved coverage of estimation, and changes in the base-year for constant price estimates (see Van der Eng, 1999, 2005). Since the 1983 revision, Indonesia's national accounts have been anchored on the quinquennial Input-Output (I-O) Tables. Consequently, the output approach still offers the main substantiation of the country's national accounts. The last of these revisions was anchored on the $2000 \mathrm{I}-\mathrm{O}$ Table.

For the purpose of this paper, the new national accounts data for 2000-08 were extrapolated back in time with 19832000 national accounts data and with broad indicators of economic activity for 1880-1983, following a methodology established in Van der Eng (1992, 2002a). This yields a GDP series in constant 2000 prices that is shown in per capita terms in Fig. 1. The chart confirms that the 1951-82 national accounts data were underestimated, and shows that Indonesia experienced periods of economic expansion, particularly sustained periods of growth during 1900-29 and 1967-97. In the latter period, average GDP growth was a significant 6.9\% per year and GDP per capita grew at 4.8\% per year. Indonesia's economy contracted drastically in 1998, but growth resumed in 1999 and the 1997 level of GDP per capita was re-achieved in 2004.

\subsection{Capital stock data}

Closely scrutinized estimates of capital stock in Indonesia are rare. Recent estimates disaggregate the growth of Gross Fixed Capital Formation (GFCF) on the basis of the quinquennial I-O Tables (Van der Eng, 2009). A perpetual inventory method was applied to 28 categories of productive assets since 1951, with the longest asset lifetime of 40 years, to estimate Gross Fixed Capital Stock (GFCS). The first 'complete' estimate is for 1990. GFCS was then re-estimated back to 1950 with the annual data on GFCF and assumed rates of asset retirement that were based on average implicit rates of asset retirement in the early 1990s. Only non-residential GFCS was used here.

For the purpose of this paper, non-residential GFCS was estimated for 1880-1941. These were based on estimates of total GFCF during these years, which were obtained as follows. In 1938, the value of GFCF was $f 272$ million, or $8.1 \%$ of GDP (CBS,

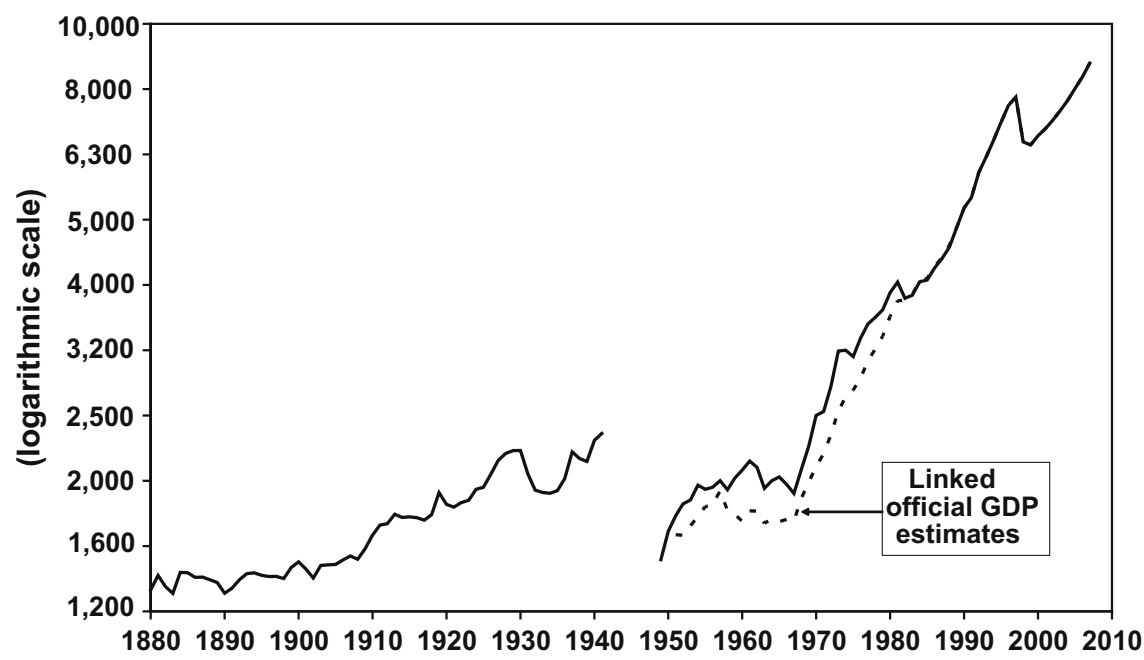

Fig. 1. GDP per Capita in Indonesia, 1880-2008 (thousand 2000 Rupiah). Sources: Table A1; population 1930-61 from Van der Eng (2002b), 1961-2008 interpolations and extrapolation of census data, 1880-1929 unpublished estimates. 


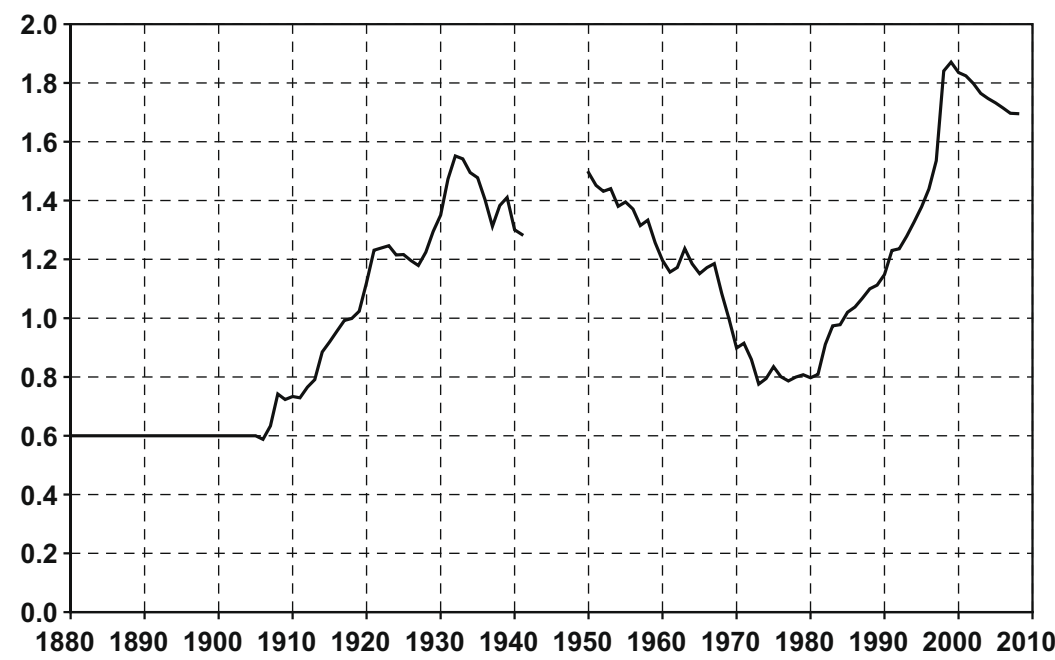

Fig. 2. Capital-output ratio for Indonesia, 1880-2008. Note: Capital stock excludes residential structures. Sources: Van der Eng (2009) updated; main text and Tables $\mathrm{A} 1$ and $\mathrm{A} 2$.

1948). ${ }^{3}$ GFCF in 1938 was extrapolated for 1880-1937 and 1939-41 with total imports of all capital goods and cement in current prices. ${ }^{4}$ The underlying assumption is that imported goods used for investment purposes had the same share in GFCF, or 32.5\%. ${ }^{5}$ GDP in current prices was calculated from Polak (1943) as NDP plus an assumed annual 6.5\% depreciation rate for 192139 , which is close to the $5.9 \%$ rate for 1938 (CBS, 1948). This GDP series was extrapolated for 1880-1920 and 1940-41 by linking the 1921-39 series to a 'reflated GDP' series, using constant price GDP estimates in Table A1 and a 'reflator' from Van der Eng (2002a: 168-73). Total GDP in 2000 prices in Table A1 was then multiplied by the resulting ratio of GFCF and GDP, both in current prices, to yield GFCF in 2000 prices for 1880-1941.

To estimate non-residential GFCS, a perpetual inventory approach was used, assuming the average productive life of all capital goods to have been 26 years, which is the implicit weighted annual average age of 27 items of non-residential capital goods in GFCS during the 1950s (Van der Eng, 2009). It is also assumed that repairs and maintenance allowed successive vintages of a capital good to deliver the same services and that scrapping took place only at the end of the service life of a capital good. Hence, the first complete estimate of capital stock was for 1906. For 1880-1905, a constant capital-output ratio (COR) of 0.6 was assumed. This is a low but credible ratio for a still largely agrarian economy such as Indonesia's prior to $1906 .^{6}$

Fig. 2 shows the results of the estimation of GFCS as a COR. The COR increased significantly from 0.6 in 1905 to 1.3 in 1929, increasing further to 1.6 in 1932 due to negative GDP growth while GFCF decreased. The COR decreased significantly from 1.3 in 1941 to 1.6 in 1950, the first year after Indonesia's full independence. This reflects the decrease in GFCS during the 1940s, as a consequence of Dutch 'scorched earth' tactics during the Japanese advance into Indonesia in early 1942, the dismantling of industrial assets and railways during the Japanese occupation of 1942-45, and damage sustained during the war of independence in 1945-49 (Keppy, 2006: 61-67). ${ }^{7}$ The increase in the COR across the 1940 s also reflects the fact that the 1941 level of GDP was not re-achieved until 1954.

During 1950-67, new GFCF of on average 8\% of GDP was just sufficient to recover capital stock, but for several years it was insufficient to compensate for the retirement of capital goods and prevent a decrease in the COR, as Fig. 2 shows. The decline continued until the rate of GFCF increased significantly in the 1970s and stopped the decrease in the COR. GFCF accelerated further during the 1980s and 1990s, bringing about an increase in the COR. The stagnation of the COR during the 1970s and until the early 1980s, despite an acceleration of GDP growth during the same years, suggests that the main sources of high

\footnotetext{
${ }^{3}$ That is, $f 42$ million investment by Indonesian firms and $f 225$ million by foreign-owned firms (CBS, 1948), to which $f 5$ million was added as government investment in public infrastructure in 1938 (CEI3, 1977). The total of $f 272$ million was considerably higher than the $f 89$ million total investment by Dutchowned companies and by the central government in fixed assets included in the annual investment series mentioned in CEI3, 1977 for 1938. The CEI3 data do not include investment by non-Dutch-owned firms, particularly by registered and unregistered ventures that by 1957 were Indonesian-owned (including investments in farm agriculture), which explains the discrepancy.

${ }^{4}$ In particular, wood and timber, cement, building glass, industrial and commercial machinery, engines, electrical equipment, railway equipment, ships, and motor vehicles. It may be possible to refine this approach on the basis of more detailed and consistent trade data (values and quantities).

${ }^{5}$ The same method was used in the national accounts during the 1950s. E.g. for 1951-55 imported capital goods were on average $25-30 \%$ of GFCF (NPB, 1957: 622).

${ }^{6}$ The COR was on average 0.66 in the UK in 1820-30, and 0.68 in Japan in 1890, calculated from capital stock estimates in Maddison (1995) and GDP data in Maddison (2003).

${ }^{7}$ The implicit estimate of the loss is $8 \%$ of capital stock in 1941. This compares with e.g. 26\% in Japan and 16\% in Germany, $10 \%$ in The Netherlands and $8 \%$ in France of pre-war capital stock (Maddison, 1995: 146-147).
} 


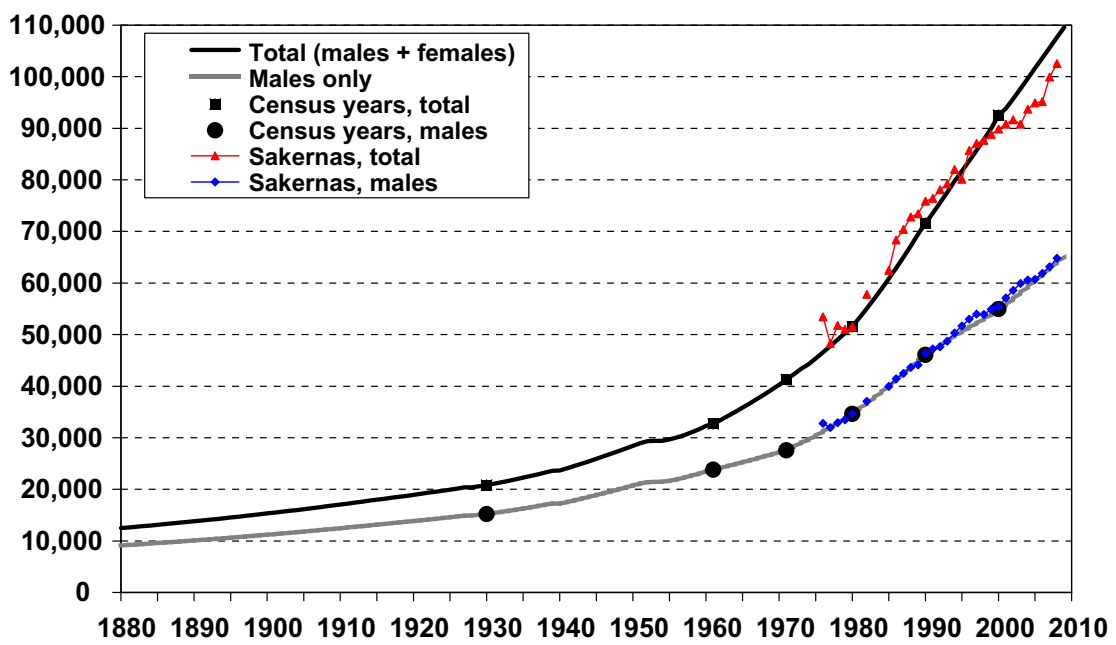

Fig. 3. Employment in Indonesia, 1880-2008 (1000). Sources: Extrapolation and interpolations of the population census data for 1930, 1961, 1971, 1980, 1990 and 2000, taking account of population growth 10 years previously; population 1930-61 from Van der Eng (2002b), 1870-1929 unpublished estimates; 1976-80, 1982 and 1985-2008 Sakernas data.

economic growth then were capital-extensive. This may be related to the fact that natural resource exploitation, particularly the rapid growth of oil production for export, underlies much of the economic expansion during these years, in combination with the mobilization of labor for new jobs in agriculture and industry. The ratio increased significantly during $1980-97$, indicating that economic growth during those years was more capital-absorbing nature and depended, at least partly, on the mobilization of productive capital. This is related to the significant growth of export-oriented manufacturing since the early 1980 s.

\subsection{Employment data}

Consistent long-term estimates of employment in Indonesia are hampered by the fact that only the population censuses of 1930,1961, 1971, 1980, 1990 and 2000 are key sources of data, even though the definitions of employment in each are slightly different. These census results have been used to extrapolate the data of the National Labor Force Survey (Survei Angkatan Kerja Nasional, Sakernas), which was conducted for 1976-80, 1982 and 1985-2008. The Sakernas definitions of employment also differ slightly over the years (Sigit, 2000a: 28-29).

Fig. 3 shows the interpolated employment data from the population censuses and also the Sakernas data. The two series track each other closely until 2000. The deviation in total employment in 2000 is possibly caused by the change in the definition of employment in Sakernas to exclude 10-14 year old workers, starting in 1998 (Sigit, 2000a: 8). Many 10-14 year olds remained gainfully employed in Indonesia, comprising 3.7, 2.9 and 2.9\% of those employed in 1980,1990 and 2000 , respectively, according to population census data. The interpolated census data are extrapolated backwards from 1930 , taking account of population growth 10 years previously, reflecting the assumption that people had for a long time gainful - but most likely part-time - employment at the age of 10 .

\subsection{Educational attainment data}

To augment the labor force data, this paper uses an indicator of per capita educational attainment in Indonesia, shown in Fig. 4. It is an approximation of long-term changes based on annual enrolments in institutions of primary, secondary and tertiary education. Fig. 4 shows that the results closely track similar data from the postwar population censuses and inter-census estimates, which suggests that they approximate the trend.

Improvement in human capital was obviously a gradual process. Educational attainment grew at a very significant rate of 3.9\% per year during 1929-67 and 3.0\% during 1967-2008, but of course from low levels. Until the 1940s, the gains were mainly due to the expansion of primary education. The share of secondary education increased after 1970, possibly in reaction to labor market changes that increased the demand for educated workers. As the method used to estimate educational attainment in Fig. 4 does not allow a disaggregation by age groups, the paper uses per capita educational attainment as a proxy for the educational attainment per person gainfully employed.

Data on the output elasticity of educational attainment are not available. However, Sakernas contains wage income data that are disaggregated by the highest stage of education that employees completed. As the number of years for each stage of education is known, it is possible to estimate the income elasticity of each additional year of education. For the years 198999 , the income elasticity of educational attainment was a fairly constant 0.11 , meaning that each additional year of education on average yields an $11 \%$ increase of income. In the absence of other data, this number is taken as a proxy for the elasticity of 


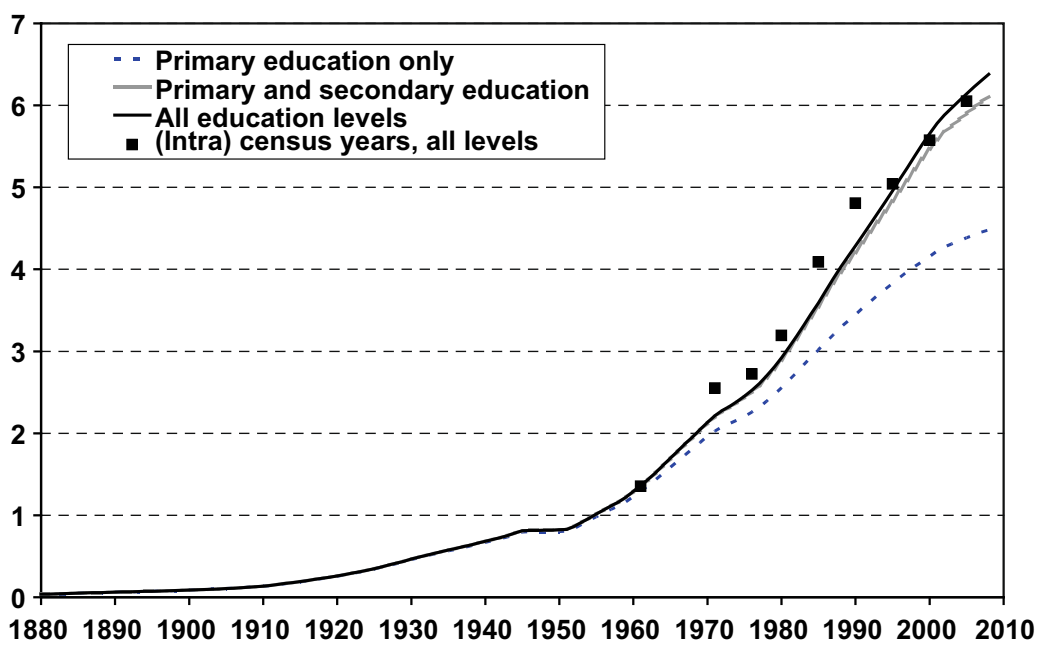

Fig. 4. Educational Attainment in Indonesia (average years of schooling per person), 1880-2008. Notes: (Intra) census years calculated by assuming that those reported as having 'incomplete primary education' had an average of 2 years of schooling, those with primary education 6 years of schooling, completed junior secondary education 9 years $(6$ years +3 years for junior high school), senior secondary 11 years $(6+3+2$ years for senior high school) and tertiary education 15 years $(6+3+2+4$ years at university). Other estimates are derived from data on primary, secondary and tertiary education enrolments during 1870-2008. Student years were accumulated on the assumption that the working life of a primary school graduate was 50 years, that of a secondary school graduate 45 years, and of a university graduate 40 years. The series of accumulated education in terms of student years were divided by population. This procedure assumes that all enrolled students actually went to school during the year. It makes no adjustment for quality differences between types of schooling or between public and private institutions, nor does it account for overseas education of Indonesian residents, or the education that migrants brought or took with them. Sources: 1961-80 census benchmarks Hugo et al. (1987: 282), 1985 BPS (1987: 123), 1990 BPS (1992: 132), 1995 BPS (1996b: 138), 2000 BPS (2002: 151), 2005 BPS (2006: 93); enrolments 1880-2008 from annual statistical publications for Indonesia and the website of the Department of Education in Indonesia, http://www.depdiknas.go.id/.

Table 1

Share of labor income in GDP in Indonesia, 1975-2005 (billion Rupiah).

\begin{tabular}{|c|c|c|c|c|c|c|c|}
\hline & \multicolumn{3}{|c|}{ Labor income } & \multirow{2}{*}{$\begin{array}{l}\text { Capital } \\
\text { income }\end{array}$} & \multirow{2}{*}{$\begin{array}{l}\text { Total GDP (factor } \\
\text { cost) }\end{array}$} & \multirow{2}{*}{$\begin{array}{l}\text { Total GDP (market } \\
\text { prices) }\end{array}$} & \multirow{2}{*}{$\begin{array}{l}\text { Labor income share } \\
(\%)\end{array}$} \\
\hline & $\begin{array}{l}\text { Wages, } \\
\text { salaries }\end{array}$ & $\begin{array}{l}\text { Income in } \\
\text { kind }\end{array}$ & Total & & & & \\
\hline 1975 & 2,853 & 2,393 & 5,245 & 8,097 & 13,342 & 13,686 & 39.3 \\
\hline 1980 & 9,491 & 9,044 & 18,535 & 29,976 & 48,511 & 48,913 & 38.2 \\
\hline 1985 & 22,904 & 19,537 & 42,441 & 53,176 & 95,617 & 98,407 & 44.4 \\
\hline 1990 & 55,738 & 37,049 & 92,787 & 104,570 & 197,357 & 210,867 & 47.0 \\
\hline 1993 & 91,479 & 59,484 & 150,963 & 156,458 & 307,420 & 329,776 & 49.1 \\
\hline 1995 & 163,376 & 98,983 & 262,359 & 248,633 & 510,993 & 542,755 & 51.3 \\
\hline 1998 & 168,585 & 109,731 & 278,316 & 700,126 & 978,442 & 989,573 & 28.4 \\
\hline 2000 & 397,579 & 244,495 & 642,074 & 725,941 & $1,368,015$ & $1,379,770$ & 46.9 \\
\hline 2003 & 690,975 & 430,548 & $1,121,523$ & 849,657 & $1,971,180$ & $2,045,854$ & 56.9 \\
\hline 2005 & $1,064,463$ & 421,705 & $1,486,168$ & $1,348,467$ & $2,834,635$ & $2,770,960$ & 52.4 \\
\hline
\end{tabular}

Sources: BPS (1996a: 72), BPS (1999: 27), BPS (2003: 35), BPS (2005: 11), BPS (2008: Appendix 5).

output with respect to education for the entire period. The estimate is in line with Collins and Bosworth (1996: 152) who found an East Asia average of $10.7 \%$.

\subsection{Factor income share data}

Although efforts are underway to estimate national income in Indonesia from the income side of the economy (Saleh and Jammal 2002), Indonesia's national accounts do not yet offer such estimates. The main sources on labor and non-labor income are the quinquennial I-O Tables and Indonesia's System of Economic and Social Accounting Matrices and Extension (SESAME) which use the I-O tables as their 'anchor' (Keuning and Saleh 2000). ${ }^{8}$ Unlike the I-O Tables, SESAME does identify non-cash labor income, as well as total wages and salaries.

\footnotetext{
${ }^{8}$ The income data in the I-O Tables comprise only the sum of wages and salaries received, which is generally estimated on the basis of Sakernas. They do not include income in kind, particularly the incomes of unpaid household workers. The income of the self-employed and of household-based ventures is included in the total operating surplus of all companies, which is not disaggregated. Sigit (2004: 103-104) solved this with multiplying average income of waged employees from Sakernas with the total number of gainfully employed, and expressing the total as a percentage of GDP. However, this yields lower labor income shares than in the SESAME tables. In addition, there is no correction for the fact that the definitions of income varied in the different Sakernas years (Sigit, 2000b: 7-9 and 17-18).
} 
Table 2

Decomposition of economic growth in Indonesia, 1881-2008.

\begin{tabular}{|c|c|c|c|c|c|c|}
\hline & $s_{l}$ & $g_{t}^{Q}$ & $g_{t}^{K}$ & $g_{t}^{L}$ & $g_{t}^{L^{*}}$ & $g_{t}^{\mathrm{TFP}}$ \\
\hline \multicolumn{7}{|c|}{ A. Annual average growth } \\
\hline 1881-99 & & 1.8 & 1.8 & 1.0 & 1.1 & 0.4 \\
\hline $1900-29$ & & 2.6 & 5.3 & 1.0 & 1.2 & -0.6 \\
\hline $1930-32$ & & -3.1 & 2.8 & 1.2 & 1.5 & -5.3 \\
\hline $1933-41$ & & 3.8 & 1.6 & 1.3 & 1.6 & 2.2 \\
\hline $1951-61$ & & 4.2 & 1.8 & 1.3 & 1.8 & 2.4 \\
\hline $1962-66$ & & 0.4 & 0.6 & 2.3 & 3.3 & -1.6 \\
\hline $1967-74$ & & 8.5 & 3.3 & 2.4 & 3.3 & 5.3 \\
\hline $1975-97$ & & 6.0 & 9.1 & 2.9 & 4.4 & -0.9 \\
\hline 1998-99 & & -6.5 & 2.9 & 2.1 & 3.7 & -9.7 \\
\hline $2000-08$ & & 5.1 & 4.0 & 2.0 & 3.1 & 1.7 \\
\hline 1881-08 & & 3.6 & 4.3 & 1.7 & 2.3 & 0.2 \\
\hline \multicolumn{7}{|c|}{ B. Contribution to growth, assuming $s_{l}=50 \%$ in $1880-1974$} \\
\hline 1881-99 & $50.0 \%$ & & $50 \%$ & & $30 \%$ & $20 \%$ \\
\hline $1900-29$ & $50.0 \%$ & & $102 \%$ & & $22 \%$ & $-24 \%$ \\
\hline $1933-41$ & $50.0 \%$ & & $21 \%$ & & $21 \%$ & $58 \%$ \\
\hline $1951-61$ & $50.0 \%$ & & $18 \%$ & & $22 \%$ & $59 \%$ \\
\hline $1967-74$ & $50.0 \%$ & & $19 \%$ & & $19 \%$ & $62 \%$ \\
\hline $1975-97$ & $44.3 \%$ & & $84 \%$ & & $32 \%$ & $-15 \%$ \\
\hline $2000-08$ & $52.4 \%$ & & $37 \%$ & & $31 \%$ & $32 \%$ \\
\hline 1881-08 & $48.9 \%$ & & $62 \%$ & & $31 \%$ & $6 \%$ \\
\hline \multicolumn{7}{|c|}{ C. Contribution to growth, assuming $s_{l}=70 \%$ in $1880-1974$} \\
\hline 1881-99 & $70.0 \%$ & & $30 \%$ & & $42 \%$ & $28 \%$ \\
\hline 1900-29 & $70.0 \%$ & & $61 \%$ & & $31 \%$ & $8 \%$ \\
\hline $1933-41$ & $70.0 \%$ & & $13 \%$ & & $29 \%$ & $59 \%$ \\
\hline $1951-61$ & $70.0 \%$ & & $13 \%$ & & $30 \%$ & $57 \%$ \\
\hline $1967-74$ & $70.0 \%$ & & $11 \%$ & & $27 \%$ & $61 \%$ \\
\hline 1881-08 & $63.6 \%$ & & $44 \%$ & & $41 \%$ & $12 \%$ \\
\hline
\end{tabular}

Notes: The annual averages are calculated as simple averages for each period. The percentages contribution may not add up to $100 \%$ due to rounding. Sources: Calculated from Tables A1 and A2, see main text.

Table 1 indicates significant changes over time in the labor income share, particularly from $51 \%$ in 1995 to a very low minimum of $28 \%$ in 1998 , when wage rates had been eroded by a drastic inflation spike. Leaving 1998 aside as a one-off aberration, these shares were interpolated for 1975-2005, and the 2005 share was used for 2005-08. No indications of the income shares of labor and capital in GDP are available before 1975. Table 1 suggests that the income share may have been $40 \%$ before 1975 , but this low share is unlikely to have applied to the entire period $1880-1974 .^{9}$ In addition, historical data for other countries suggest that these shares are likely to have been subject to significant annual fluctuations over time. The best possible solution here is to test the sensitivity of the results by assuming plausible factor income shares. The paper uses labor income shares of $50 \%$ and $70 \%$ for that purpose in the next section. ${ }^{10}$

All data presented in this section are necessarily rough, given the difficulties in the compilation of statistical data for Indonesia in both past and present. These difficulties increase further back in time. Still, the data are based on the best possible available information and are reasonably robust.

\section{The proximate sources of economic growth}

The data in Section 3 allow the disaggregation of GDP growth and the identification of the key proximate explanations of growth. Table 2 reveals the contribution of TFP growth to economic growth for key growth periods identified on the basis of Fig. 1. The table shows that TFP growth has on average been low during 1880-2008, explaining only 6-12\% of the annual average 3.6\% GDP growth. Most economic growth can be explained on the basis of the mobilization of capital and labor, and improvements in the quality of labor, although the relative share of both key production factors in explaining growth depends on what their respective actual income shares were.

Notably, during 1900-29, TFP growth was negative to marginal, despite the fact that this was a period during which the country must have experienced the impact of a range of potentially productivity-enhancing imported and home-grown tech-

\footnotetext{
9 The 1975 share of $39 \%$ seems very low, but capital income comprised the imputed income from the productive use of land, most of which was owned by small farming households. In an economy where agriculture was the most important single sector in terms of employment and income, as was the case in Indonesia before the 1970 s, income from land may have been relatively significant.

${ }^{10}$ Which is roughly the band in which the labor income share in Spain fluctuated over time (Prados and Rosés, 2007: Fig. 8). In the US, the labor income share was 65\% during 1800-55 and 55\% during 1855-90 (Abramovitz and David, 2001: 20), roughly the same as in the UK and France in the late 19th century (Prados and Rosés, 2003: 50).
} 
Table 3

TFP contribution to economic growth in Indonesia in various studies.

\begin{tabular}{|c|c|c|c|c|}
\hline & Source & Period & Annual average TFP growth (\%) & $\%$ TFP contribution to output growth \\
\hline 1 & Baier et al. (2006: 45) & $1951-2000$ & -0.7 & -37 \\
\hline 2 & Bosworth et al. (1995: Table A2) & $1960-92$ & 0.5 & 17 \\
\hline 3 & Collins and Bosworth (1996: 157) & 1960-94 & 0.8 & 23 \\
\hline 4 & Firdausy (2005: 12) & $1961-2000$ & -1.5 & -27 \\
\hline 5 & Drysdale and Huang (1997: 208) & $1962-90$ & 2.1 & 31 \\
\hline 6 & Lindauer and Roemer (1994: 3) & 1965-90 & 2.7 & 42 \\
\hline 7 & Young (1994: 243) & $1970-85$ & 1.2 & 24 \\
\hline 8 & Kawai (1994: 384) & 1970-90 & 1.5 & 24 \\
\hline 9 & Sarel (1997: 29) & $1978-96$ & 1.2 & 25 \\
\hline 10 & Sigit (2004: 104-5) & 1980-2000 & -0.8 & -15 \\
\hline 11 & This study ${ }^{a}$ & 1951-2008 & 0.6 & 12 \\
\hline
\end{tabular}

Notes: The different results are due to differences in (a) the period considered, (b) the basic data used, (c) the ways in which the key variables for growth accounting were constructed, (d) variables used to account for growth.

a Assuming 60\% labor income share $1951-74$, unlike the $50 \%$ and $70 \%$ in Table 2.

nologies, as well as institutional changes. Arguably the most important technological changes were in transport and communications and in the production of key export commodities (Van der Eng, 2002a: 153-54). Together with the low contribution of TFP growth (only 10-11\%) during the high-growth era of 1967-97, this finding may be further evidence of the 'Solow Productivity Paradox'.

Table 2 reveals remarkably significant contributions of TFP growth to GDP growth during four periods in particular: $1933-41$ (58-59\% of 3.8\% average annual growth), 1951-61 (57-59\% of 4.2\%), 1967-74 (61-62\% of 8.5\%) and 2000-08 (32\% of 5.1\%). What do these periods have in common? The figures for TFP and GDP growth during 1941-49 are not known, but it can be assumed that they were negative. If so, all four periods came after significant setbacks in Indonesia's economic development: respectively the 1930-32 crisis, the 1942-49 Japanese occupation followed by the war of independence, the mounting political and economic chaos of the early 1960s, and the 1997-98 crisis. All four setbacks caused a slowdown in GFCF and in GFCS growth. Consequently, subsequent economic recovery was based in first instance on a more efficient use of productive resources, particularly capital stock, assisted by economic policy and institutional changes that enhanced productivity and efficiency.

After 1930-32, this change took the form of import-replacing development strategies to offset the consequences of falling commodity export earnings and later to prepare for the impact of World War II on Indonesia's foreign trade. This policy stance benefited food production and manufacturing, but was interrupted during 1942-49. It resumed after the country's independence, particularly in the face of falling commodity export earnings in the wake of the 1951-52 Korea boom. But this period of expansion ended when an accumulation of erratic policies under President Sukarno paralyzed the economy during 1959-66. The regime change of 1966 eventually resulted in economic stabilization and a phase of rapid economic growth during 1967-97 under President Soeharto. This was carried by significant TFP growth during 1967-74, until GFCF took over as the main factor spurring economic growth during 1975-97. In each case, policy reforms took a few years to crystallize before their full impact was felt, and GFCF increased.

Table 3 compares this paper's estimates of TFP growth and its contribution to economic growth in Indonesia with those of other studies. The table shows significant differences in the results of all studies, but particularly between those of studies $2-$ 3 and 5-9 and those of Baier et al. (2006), Sigit (2004), Firdausy (2005) and this study. Studies 1-9 paid hardly any attention to the intricacies of Indonesia's statistical data and their consequences for growth accounting. It may therefore be appropriate to use their results with caution.

One of the reasons for the different results in Table 3 is the fact that authors often used different data sets and/or different ways to process the data, generally without regard for the inherent problems in the underlying data sets. For example, several of the multi-country studies obtained output data from the Penn World Tables (PWT), which in turn obtained them from the World Bank's World Development Indicators. However, there are many unexplained anomalies between the PWT data and the official data from BPS, Indonesia's statistical agency. For example, PWT gives total population estimates for Indonesia as 124.7 million in 1971, 154.4 million in 1980, 188.0 million in 1990 and 224.1 million in 2000, while Indonesia's population censuses give totals of respectively $118.4,147.0,178.5$ and 206.2 million. PWT also presents GDP in international prices, even though Indonesia featured only twice - in 1980 and 1996 - in the six benchmarks of the International Comparisons Project. Hence, PWT estimated the key expenditure components of GDP for most years in its Indonesian time series on the basis of its multilateral 'shortcut approach', but without consideration of the degree of underestimation in Indonesia's national accounts data. In addition, several multi-country studies took capital stock data from Nehru and Dhareshwar (1993), which were based on aggregated investment data obtained from the World Bank that took no account of underestimation, and on highly arbitrary assumptions, such as that of a single 'decay rate' of 4\% for all countries. Baier et al. (2006) used Mitchell's handbooks of historical statistics as key sources, but without accounting for inconsistencies in e.g. the national accounts data, and simply interpolating years for which data were missing, without due account of the availability of other data for Indonesia. 
Table 4

TFP growth in manufacturing in Indonesia in various studies.

\begin{tabular}{lllll}
\hline & Study & Period & Annual average TFP growth (\%) & \% TFP contribution to output growth \\
\hline 1 & Aswicahyono and Hill (2002: 148) & $1975-93$ & 2.7 & 21 \\
2 & Timmer (1999: 87-89) & $1975-95$ & 2.8 & 22 \\
3 & Vial (2006: 367) & $1976-96$ & 3.5 & $35^{\mathrm{a}}$ \\
4 & Hayashi (2005: 99, 107) & $1986-96$ & 1.9 (SMEs) & 17 \\
& & & 2.3 (LEs) & 1.6 \\
\hline
\end{tabular}

a This source does not specify output growth, which for this table is calculated from national accounts data.

Hence, it is difficult to check whether the different estimates of TFP growth from the multi-country studies are true differences or the consequences of measurement errors and/or the assumptions underlying data processing. For the same reason it is not possible to explain in detail the differences in the results of studies 1-9 and the findings of this paper. Only in the case of Sigit (2004) is it possible to explain the discrepancy, because Sigit clearly overestimated capital stock growth, which was based on an incomplete and unpublished BPS estimate, while he also underestimated the share of labor income in total income by counting only wage income from Sakernas and excluding income in kind.

Several studies have estimated TFP on the basis of the firm-level data from the annual survey of industrial firms in Indonesia employing 20 or more people. The results are shown in Table 4 . They all suggest that in manufacturing TFP growth has been modest, but significant and positive.

To put the results of this paper in context, it has to be noted that the results in Table 2 do not necessarily indicate that there was no technological change in Indonesia that contributed to long-term economic growth. One of the key reasons for the different results shown in Table 3 is, as Chen (1997: 23-26) noted, the fundamental difficulty of measuring capital input, and the fact that TFP is consequently a fairly arbitrary concept. There are at least two fundamental problems with this paper's calculation of TFP growth: (1) it is estimated as a residual, and (2) it assumes perfect elasticity of substitution of labor and capital.

The measurement of TFP growth as a residual means that TFP does not account for the fact that some aspects of technological change may already have been captured in the measurement of capital stock and education-adjusted employment. As capital accumulation tends to be the main vehicle of technological change, much of the technology is embodied in the stock of capital goods. This fundamental issue is likely to be significant for Indonesia in recent decades, given the high rate of capital accumulation since the early 1980s, as Fig. 2 showed. Hence, most of the current non-residential capital stock is of recent vintage, and is likely to embody recent technologies. In addition, in manufacturing, investment in machinery and equipment was predominant and sustained most of the rapid growth of output in that sector (Timmer, 1999: 83 and 89). Some technological change and efficiency gains were captured in the rates of TFP growth in manufacturing in Table 4, but other gains were most likely captured in the measured industrial capital stock, and cannot be disentangled. ${ }^{11}$ On the other hand, as most investment outside manufacturing may have been in the form of non-residential structures, particularly investment in public infrastructure, the embodied efficiency gains may not have been as significant as was the case in manufacturing.

Likewise, the measurement of education-augmented employment may have captured some technological change that would otherwise be measured as part of TFP. After all, the significant improvement in educational attainment explains one-third of the contribution of employment to economic growth during 1967-74 and 1975-97, shown in Table 2. Several of the studies in Table 3 did not adjust for changes in educational attainment. Hence, without the education adjustment, TFP growth in Table 2 would have been higher.

For those reasons, this paper's measure of TFP growth - and that of other studies as well - may be less a measure of technological change and increased efficiency of production than simply an unexplained residual that comprises a wide range of factors related to Indonesia's business environment as they impacted on the efficiency of production. Hence, low or negative TFP growth may rather reflect a multitude of inefficiencies in Indonesia's economy at large that impacted negatively on the productivity of firms rather than the general performance of firms. If TFP growth was indeed positive in manufacturing, as Table 4 suggests, such inefficiencies may have existed in the non-manufacturing sectors of the economy. They may for example have taken the form of imperfections in particularly non-tradable sectors in non-manufacturing and services, such as transport and communications, and/or in labor, capital and commodity markets, possibly related to inhibiting regulations, the lack of exposure to foreign competition, the dominance of state-owned enterprises, and/or the presence of opportunities for anti-competitive behavior.

A possible indication that TFP growth measures the residual is the fact that during 2000-08 the residual became positive, explaining a significant 32\% of GDP growth. GFCF was relatively low during these years, while the growth of employment was steady. In addition, there may have been productive overcapacity by 1999 that came to be used more efficiently during 2000-08. Still, this change may be understood as an improvement in efficiency caused by the many growth-enhancing, or

$\overline{11}$ See e.g. Maddison (1987: 663-664) for a discussion of the problem of technology embodiment in capital stock and the difficulty of accounting for it. 


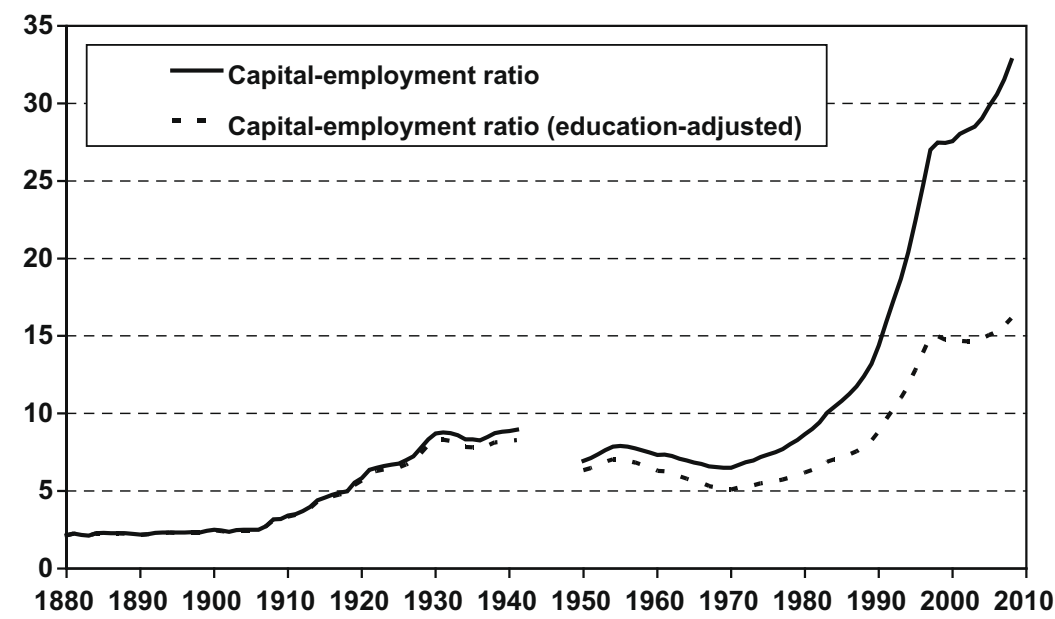

Fig. 5. Capital stock per person employed in Indonesia, 1880-2008 (million 2000 Rp). Source: Appendix 6.

rather inefficiency-decreasing, institutional changes that recent governments have introduced in Indonesia (Van der Eng, 2004). For example, deregulation and re-regulation in various ways enhanced competition in previously non-tradable sectors. Likewise, new capital market regulation imposed greater discipline on listed firms. While these changes may have increased uncertainty among foreign investors about investing in Indonesia, they may at the same time have been an encouragement for firms in Indonesia with a more intimate knowledge of past and current idiosyncrasies and risk in Indonesia's business environment, and ways to hedge it.

Secondly, and related to the first point, available growth accounting studies implicitly assume that there is perfect elasticity of substitution between labor and capital. This paper did the same in Eq. (5). However, as Rodrik (1998: 84-8) has argued, it cannot be automatically assumed that this is the case. If, for example, economic growth and technological change had either a labor-saving or a capital-saving nature, the elasticity of substitution would be respectively more than, and less than 1 . Hence, if technological change in Indonesia in recent decades was to a degree labor-saving and capital-absorbing, the process will have yielded a downward bias of the estimated rate of TFP growth. The bias may be in proportion to the capitallabor ratio, which indeed increased very significantly in Indonesia, as Fig. 5 shows, particularly during 1988-97, and to a lesser degree during 1906-29 and 1970-87. Although this point can be readily made, it is not easy to quantify its implications for efforts to account for economic growth.

\section{Conclusion}

This paper estimates that the contribution of TFP growth to GDP growth, after accounting for the growth of non-residential capital stock and education-adjusted employment, was on average a low 7-13\% during 1880-2008. It also estimates that the growth of capital stock was responsible for a large part of GDP growth - 44-61\% over the whole of this period, and 56-61\% during the rapid growth years of 1967-98. Hence, the case of Indonesia appears to offer support for Krugman's thesis that economic growth in East Asia in recent decades was 'perspiration', rather than 'inspiration'based.

However, the paper notes that capital stock in Indonesia is likely to have contained embodied technology, while the education adjustment of employment is also likely to have captured part of the productivity growth that must have occurred, particularly during the key growth periods 1900-29 and 1975-97. Hence, the measure of residual TFP growth offered in the paper is more likely a reflection of a wide range of factors that impact on economic growth, but that the paper could not account for in ways done in other growth accounting studies. Such studies (e.g. Maddison, 1987; Crafts, 2004) have generally been able to draw on a much wider range of historical statistical data than are available for Indonesia.

The negative residual TFP growth during 1900-29 and 1975-97 may be taken as reflections of a range of inefficiencies that existed in the Indonesian economy at the time, despite a range of other efficiency-enhancing technological and institutional changes that occurred at the same time. Support for that suggestion is found in the fact that TFP growth was significantly positive during 1933-41, 1951-61, 1967-74 and 2000-08, always following periods of economic recession or stagnation. During each of these periods, economic recovery may have been based in the first instance on a more productive use of available resources, particularly capital stock, and in the second instance, on the fact that preceding periods of recession or stagnation had magnified the economic inefficiencies that were then assessed, addressed and reduced, leading to economic policy and institutional changes that enhanced efficiency, leading successively to growth of GFCF that reduced measured TFP growth. 


\section{Appendix}

Table A1

Gross value added in 17 output sectors in Indonesia, 1880-2008 (billion 2000 Rupiah).

\begin{tabular}{|c|c|c|c|c|c|c|c|c|c|c|c|c|c|c|c|c|c|c|}
\hline & $\begin{array}{l}\text { Food } \\
\text { crops }\end{array}$ & $\begin{array}{l}\text { Animal } \\
\text { husbandry }\end{array}$ & $\begin{array}{l}\text { Farm } \\
\text { cash } \\
\text { crops }\end{array}$ & $\begin{array}{l}\text { Estate } \\
\text { crops }\end{array}$ & Fisheries & Forestry & Mining & Manufacturing & Utilities & Construction & Trade & $\begin{array}{l}\text { Transport, } \\
\text { communications }\end{array}$ & $\begin{array}{l}\text { Financial } \\
\text { services }\end{array}$ & Housing & $\begin{array}{l}\text { Public } \\
\text { administration }\end{array}$ & $\begin{array}{l}\text { Other } \\
\text { services }\end{array}$ & Oil, Gas & Total \\
\hline 1880 & 12,933 & 4,244 & 710 & 135 & 1,290 & 357 & 1,806 & 4,443 & 1 & 273 & 6,214 & 373 & 937 & 5,494 & 982 & 4,446 & 0 & 44,638 \\
\hline 81 & 14,447 & 4,299 & 837 & 185 & 1,304 & 432 & 1,676 & 4,488 & 1 & 278 & 6,533 & 390 & 1,399 & 5,570 & 1,023 & 4,607 & 0 & 47,470 \\
\hline 82 & 13,284 & 4,351 & 734 & 184 & 1,311 & 388 & 1,536 & 4,513 & 1 & 347 & 6,375 & 415 & 1,397 & 5,422 & 1,065 & 4,544 & 0 & 45,868 \\
\hline 83 & 12,621 & 4,410 & 733 & 202 & 1,327 & 395 & 1,449 & 4,570 & 2 & 305 & 6,344 & 491 & 1,437 & 5,352 & 1,178 & 4,551 & 0 & 45,367 \\
\hline 84 & 14,605 & 4,469 & 801 & 227 & 1,341 & 435 & 1,661 & 4,616 & 2 & 333 & 6,798 & 546 & 1,642 & 5,647 & 1,446 & 4,768 & 0 & 49,338 \\
\hline 1885 & 15,175 & 4,537 & 803 & 202 & 1,366 & 425 & 1,453 & 4,701 & 2 & 309 & 6,907 & 626 & 1,708 & 5,712 & 1,426 & 4,856 & 0 & 50,206 \\
\hline 86 & 14,682 & 4,620 & 940 & 216 & 1,390 & 489 & 1,451 & 4,784 & 1 & 354 & 6,959 & 632 & 1,733 & 5,685 & 1,404 & 4,902 & 0 & 50,241 \\
\hline 87 & 14,695 & 4,702 & 867 & 199 & 1,409 & 451 & 1,951 & 4,851 & 1 & 448 & 6,991 & 649 & 1,786 & 5,686 & 1,342 & 4,976 & 0 & 51,003 \\
\hline 88 & 14,326 & 4,784 & 920 & 195 & 1,427 & 472 & 1,963 & 4,911 & 1 & 422 & 7,055 & 704 & 1,848 & 5,667 & 1,461 & 5,017 & 0 & 51,171 \\
\hline 89 & 14,030 & 4,864 & 909 & 220 & 1,439 & 478 & 1,754 & 4,954 & 1 & 381 & 7,148 & 848 & 1,897 & 5,663 & 1,469 & 5,039 & 0 & 51,094 \\
\hline 1890 & 13,567 & 4,961 & 793 & 217 & 1,475 & 427 & 1,677 & 5,078 & 1 & 418 & 7,059 & 951 & 1,850 & 5,591 & 1,285 & 5,073 & 0 & 50,423 \\
\hline 91 & 13,555 & 5,002 & 983 & 237 & 1,483 & 516 & 1,991 & 5,107 & 1 & 456 & 7,215 & 1,095 & 1,903 & 5,654 & 1,289 & 5,150 & 0 & 51,638 \\
\hline 92 & 15,121 & 5,055 & 1,028 & 244 & 1,503 & 538 & 2,184 & 5,174 & 1 & 403 & 7,449 & 1,154 & 1,780 & 5,813 & 1,161 & 5,297 & 0 & 53,905 \\
\hline 93 & 16,112 & 5,107 & 828 & 231 & 1,502 & 448 & 2,174 & 5,171 & 2 & 386 & 7,551 & 1,169 & 1,818 & 5,896 & 1,262 & 5,353 & 0 & 55,010 \\
\hline 94 & 15,533 & 5,155 & 1,045 & 267 & 1,522 & 555 & 2,385 & 5,241 & 2 & 485 & 7,674 & 1,218 & 1,876 & 5,897 & 1,481 & 5,429 & 169 & 55,935 \\
\hline 1895 & 16,076 & 5,220 & 914 & 156 & 1,549 & 452 & 2,071 & 5,335 & 2 & 348 & 7,704 & 1,310 & 1,981 & 5,913 & 1,659 & 5,503 & 254 & 56,446 \\
\hline 96 & 15,446 & 5,232 & 1,058 & 269 & 1,568 & 561 & 2,193 & 5,397 & 2 & 494 & 7,799 & 1,386 & 1,977 & 5,908 & 1670 & 5,551 & 340 & 56,849 \\
\hline 97 & 16,107 & 5,252 & 1,009 & 306 & 1,594 & 556 & 2,477 & 5,489 & 2 & 543 & 7,858 & 1,485 & 1,756 & 5,952 & 1,234 & 5,635 & 593 & 57,848 \\
\hline 98 & 15,315 & 5,273 & 1,071 & 325 & 1,622 & 591 & 2,659 & 5,583 & 2 & 590 & 7,919 & 1,577 & 2,011 & 5,922 & 1,547 & 5,711 & 677 & 58,394 \\
\hline 99 & 16,858 & 5,294 & 1,150 & 370 & 1,650 & 643 & 3,098 & 5,679 & 2 & 593 & 8,248 & 1,860 & 2,261 & 6,132 & 1,573 & 5,935 & 423 & 61,768 \\
\hline 1900 & 17,289 & 5,317 & 1,213 & 373 & 1,678 & 671 & 4,024 & 5,776 & 3 & 634 & 8,429 & 2,084 & 2,205 & 6,197 & 1,592 & 6,097 & 509 & 64,089 \\
\hline 01 & 17,121 & 5,318 & 1,215 & 360 & 1,699 & 666 & 3,234 & 5,848 & 3 & 641 & 8,422 & 2,242 & 1,970 & 6,166 & 1,319 & 6,078 & 931 & 63,234 \\
\hline 02 & 15,665 & 5,322 & 1,396 & 443 & 1,720 & 778 & 2,687 & 5,920 & 3 & 880 & 8,392 & 2,515 & 2,008 & 6,112 & 1,528 & 6,080 & 593 & 62,041 \\
\hline 03 & 17,007 & 5,327 & 1,372 & 471 & 1,741 & 780 & 3,511 & 5,993 & 4 & 776 & 8,571 & 2,699 & 2,030 & 6,237 & 1,519 & 6,262 & 1,357 & 65,657 \\
\hline 04 & 17,605 & 5,334 & 1,318 & 458 & 1,762 & 751 & 2,818 & 6,068 & 4 & 821 & 8,735 & 2,881 & 2,184 & 6,313 & 1,684 & 6,350 & 1,528 & 66,614 \\
\hline 1905 & 17,542 & 5,340 & 1,589 & 474 & 1,784 & 873 & 2,280 & 6,143 & 5 & 783 & 8,943 & 3,080 & 2,281 & 6,369 & 1,746 & 6,424 & 1,863 & 67,519 \\
\hline 06 & 18,712 & 5,395 & 1,514 & 500 & 1,805 & 852 & 2,284 & 6,215 & 6 & 787 & 9,144 & 3,270 & 2,366 & 6,489 & 1,661 & 6,559 & 1,863 & 69,420 \\
\hline 07 & 18,567 & 5,452 & 1,805 & 537 & 1,827 & 991 & 2,518 & 6,288 & 6 & 1,003 & 9,309 & 3,633 & 2,249 & 6,558 & 1,522 & 6,668 & 2,286 & 71,217 \\
\hline 08 & 18,069 & 5,510 & 1,671 & 539 & 1,848 & 935 & 2,679 & 6,363 & 6 & 968 & 9,256 & 3,922 & 2,285 & 6,519 & 1,588 & 6,717 & 2,377 & 71,251 \\
\hline 09 & 19,917 & 5,568 & 1,614 & 517 & 1,870 & 901 & 2,580 & 6,438 & 7 & 970 & 9,581 & 4,291 & 2,545 & 6,719 & 1,782 & 6,946 & 2,540 & 74,787 \\
\hline 1910 & 21,282 & 5,628 & 1,749 & 551 & 1,892 & 973 & 3,260 & 6,514 & 8 & 1,237 & 10,011 & 4,786 & 2,745 & 6,936 & 2,052 & 7,242 & 2,540 & 79,407 \\
\hline 11 & 21,912 & 5,689 & 1,705 & 681 & 1,915 & 1,010 & 4,395 & 6,592 & 9 & 1,363 & 10,240 & 5,533 & 2,838 & 7,073 & 2,010 & 7,485 & 2,794 & 83,242 \\
\hline 12 & 21,657 & 5,815 & 1,998 & 640 & 1,937 & 1,116 & 4,869 & 6,670 & 10 & 1,537 & 10,357 & 6,087 & 2,757 & 7,133 & 1,876 & 7,645 & 2,547 & 84,650 \\
\hline 13 & 22,431 & 5,942 & 1,846 & 643 & 1,960 & 1,053 & 5,516 & 6,748 & 12 & 2,019 & 10,626 & 6,560 & 2,912 & 7,270 & 2,498 & 7,900 & 2,625 & 88,559 \\
\hline 14 & 22,838 & 6,148 & 1,831 & 637 & 1,983 & 1,044 & 4,426 & 6,827 & 13 & 1,772 & 10,720 & 6,732 & 3,039 & 7,309 & 2,707 & 7,920 & 2,625 & 88,572 \\
\hline 1915 & 23,519 & 6,248 & 1,783 & 640 & 2,006 & 1,025 & 3,768 & 6,906 & 14 & 1,914 & 10,846 & 6,674 & 3,422 & 7,389 & 2,799 & 8,038 & 2,794 & 89,785 \\
\hline 16 & 22,385 & 6,188 & 1,750 & 800 & 2,030 & 1,078 & 5,101 & 6,987 & 15 & 1,825 & 10,800 & 7,038 & 3,436 & 7,324 & 2,788 & 8,141 & 2,887 & 90,572 \\
\hline 17 & 23,450 & 6,134 & 1,565 & 831 & 2,053 & 1,013 & 3,849 & 7,069 & 16 & 1,745 & 10,817 & 7,167 & 3,564 & 7,381 & 2,932 & 8,205 & 3,048 & 90,841 \\
\hline
\end{tabular}




\begin{tabular}{|c|c|c|c|c|c|c|c|c|c|c|c|c|c|c|c|c|c|c|}
\hline 18 & 24,763 & 6,059 & 1,781 & 848 & 2,054 & 1,112 & 3,458 & 7,072 & 17 & 2,068 & 11,151 & 7,245 & 3,468 & 7,531 & 2,793 & 8,298 & 2,963 & 92,683 \\
\hline 19 & 25,605 & 5,988 & 2,974 & 680 & 2,081 & 1,546 & 5,065 & 7,166 & 18 & 1,581 & 11,943 & 8,311 & 4,473 & 7,828 & 3,919 & 8,746 & 3,556 & 101,480 \\
\hline 1920 & 23,631 & 5,890 & 2,416 & 765 & 2,109 & 1,346 & 4,300 & 7,260 & 20 & 2,449 & 11,508 & 9,590 & 3,416 & 7,673 & 3,549 & 8,654 & 4,066 & 98,644 \\
\hline 21 & 22,037 & 6,024 & 2,504 & 798 & 2,134 & 1,397 & 4,401 & 7,347 & 23 & 2,233 & 11,576 & 10,231 & 3,607 & 7,621 & 4,209 & 8,785 & 3,934 & 98,861 \\
\hline 22 & 24,169 & 6,088 & 2,623 & 880 & 2,160 & 1,481 & 4,728 & 7,435 & 24 & 2,156 & 11,780 & 9,601 & 3,894 & 7,758 & 3,899 & 9,023 & 3,959 & 101,657 \\
\hline 23 & 23,810 & 6,284 & 2,915 & 923 & 2,186 & 1,623 & 5,315 & 7,525 & 25 & 2,317 & 11,971 & 9,368 & 4,282 & 7,799 & 3,638 & 9,122 & 4,609 & 103,709 \\
\hline 24 & 24,861 & 6,455 & 3,447 & 1,015 & 2,212 & 1,887 & 5,761 & 7,615 & 26 & 2,220 & 12,637 & 9,802 & 5,195 & 8,043 & 3,705 & 9,471 & 4,749 & 109,100 \\
\hline 1925 & 23,716 & 6,939 & 3,712 & 1,193 & 2,239 & 2,075 & 5,330 & 7,707 & 27 & 2,811 & 13,118 & 10,476 & 5,134 & 8,133 & 3,986 & 9,664 & 4,969 & 111,230 \\
\hline 26 & 25,747 & 7,240 & 3,840 & 1,120 & 2,266 & 2,125 & 6,589 & 7,801 & 30 & 3,195 & 13,627 & 11,265 & 5,198 & 8,379 & 4,396 & 10,090 & 4,928 & 117,834 \\
\hline 27 & 26,973 & 7,373 & 4,145 & 1,302 & 2,293 & 2,408 & 6,810 & 7,896 & 33 & 3,618 & 14,212 & 12,570 & 5,455 & 8,651 & 4,699 & 10,493 & 6,370 & 125,299 \\
\hline 28 & 26,029 & 7,823 & 4,499 & 1,499 & 2,321 & 2,567 & 6,981 & 7,992 & 37 & 4,213 & 14,678 & 13,800 & 5,318 & 8,776 & 5,212 & 10,706 & 7,450 & 129,901 \\
\hline 29 & 24,408 & 7,566 & 4,496 & 1,522 & 2,350 & 2,870 & 7,082 & 8,743 & 42 & 4,882 & 14,979 & 14,802 & 4,781 & 8,790 & 5,601 & 10,812 & 9,112 & 132,837 \\
\hline 1930 & 26,969 & 7,279 & 4,180 & 1,526 & 2,378 & 2,145 & 7,016 & 9,900 & 47 & 4,097 & 15,134 & 14,216 & 4,559 & 8,823 & 5,677 & 10,912 & 9,680 & 134,540 \\
\hline 31 & 26,375 & 7,087 & 4,171 & 1,539 & 2,414 & 1,674 & 5,733 & 9,261 & 48 & 3,041 & 14,269 & 12,860 & 4,403 & 8,487 & 5,449 & 10,704 & 8,244 & 125,759 \\
\hline 32 & 27,520 & 6,634 & 4,082 & 1,470 & 2,449 & 1,304 & 3,358 & 8,016 & 45 & 2,563 & 13,372 & 11,974 & 4,463 & 8,278 & 5,369 & 10,528 & 9,045 & 120,471 \\
\hline 33 & 28,115 & 6,465 & 4,215 & 1,171 & 2,485 & 1,096 & 3,046 & 8,860 & 43 & 2,173 & 13,607 & 11,209 & 4,652 & 8,270 & 5,315 & 10,601 & 9,900 & 121,224 \\
\hline 34 & 25,846 & 6,595 & 4,838 & 1,045 & 2,522 & 1,237 & 3,940 & 9,954 & 41 & 2,129 & 14,026 & 10,836 & 4,634 & 8,232 & 5,335 & 10,693 & 10,793 & 122,697 \\
\hline 1935 & 28,402 & 6,783 & 4,738 & 938 & 2,559 & 1,355 & 4,600 & 9,545 & 43 & 2,463 & 14,218 & 9,728 & 4,853 & 8,322 & 5,242 & 10,878 & 10,942 & 125,612 \\
\hline 36 & 30,132 & 6,667 & 4,987 & 1,010 & 2,597 & 1,507 & 6,186 & 9,602 & 47 & 2,738 & 14,650 & 10,339 & 5,407 & 8,527 & 5,737 & 11,284 & 11,604 & 133,020 \\
\hline 37 & 29,759 & 7,805 & 5,549 & 1,419 & 2,635 & 1,923 & 7,771 & 13,262 & 52 & 3,108 & 17,502 & 11,517 & 5,680 & 9,071 & 6,077 & 12,060 & 13,158 & 148,348 \\
\hline 38 & 31,383 & 6,980 & 5,202 & 1,290 & 2,674 & 1,989 & 5,469 & 12,531 & 58 & 3,464 & 16,922 & 12,278 & 5,614 & 9,057 & 6,689 & 12,092 & 13,296 & 146,989 \\
\hline 39 & 31,525 & 7,213 & 5,293 & 1,420 & 2,714 & 2,036 & 5,755 & 12,357 & 65 & 3,942 & 16,825 & 12,286 & 5,030 & 9,053 & 5,634 & 12,184 & 14,402 & 147,733 \\
\hline 1940 & 33,237 & 7,245 & 5,446 & 1,492 & 2,754 & 2,172 & 8,838 & 14,138 & 90 & 4,284 & 18,166 & 11,920 & 7,437 & 9,425 & 7,507 & 12,972 & 14,385 & 161,510 \\
\hline 41 & 34,549 & 7,397 & 5,786 & 1,553 & 2,863 & 2,397 & 10,275 & 15,256 & 94 & 4,032 & 19,118 & 12,980 & 8,361 & 9,701 & 7,799 & 13,480 & 12,458 & 168,099 \\
\hline 49 & 30,075 & 6,859 & 4,314 & 532 & 2,492 & 1,010 & 5,548 & 7,434 & 68 & 2,531 & 12,744 & 6,961 & 4,444 & 7,980 & 3,186 & 11,115 & 10,023 & 117,313 \\
\hline 1950 & 28,104 & 7,033 & 7,269 & 565 & 2,329 & 1,489 & 6,168 & 10,262 & 74 & 2,533 & 14,803 & 8,504 & 5,137 & 8,383 & 6,072 & 11,966 & 11,227 & 131,918 \\
\hline 51 & 29,091 & 7,286 & 8,343 & 713 & 3,040 & 1,445 & 6,316 & 13,101 & 81 & 3,035 & 17,002 & 9,371 & 4,692 & 8,796 & 4,435 & 12,464 & 12,864 & 142,075 \\
\hline 52 & 28,367 & 8,044 & 7,303 & 884 & 3,414 & 1,820 & 6,827 & 13,817 & 87 & 4,159 & 17,965 & 9,349 & 5,344 & 8,947 & 5,943 & 14,176 & 14,497 & 150,943 \\
\hline 53 & 29,981 & 7,898 & 6,088 & 995 & 3,678 & 1,889 & 6,511 & 13,845 & 104 & 3,807 & 17,868 & 10,466 & 5,670 & 9,026 & 5,828 & 14,848 & 17,409 & 155,912 \\
\hline 54 & 33,584 & 7,966 & 7,468 & 997 & 3,748 & 1,701 & 6,739 & 14,533 & 109 & 4,690 & 18,974 & 11,182 & 6,869 & 9,433 & 5,391 & 15,561 & 18,449 & 167,394 \\
\hline 1955 & 30,953 & 8,841 & 7,030 & 1,010 & 3,994 & 1,894 & 6,219 & 15,301 & 123 & 5,279 & 19,124 & 12,463 & 6,388 & 9,459 & 4,316 & 15,734 & 19,944 & 168,073 \\
\hline 56 & 31,557 & 9,036 & 6,728 & 980 & 4,257 & 1,805 & 5,715 & 16,302 & 127 & 5,692 & 20,199 & 11,957 & 6,360 & 9,570 & 4,623 & 16,014 & 21,635 & 172,558 \\
\hline 57 & 31,862 & 8,639 & 6,735 & 993 & 4,339 & 1,904 & 5,482 & 16,971 & 128 & 5,193 & 20,072 & 12,260 & 7,568 & 9,643 & 5,389 & 16,284 & 26,422 & 179,884 \\
\hline 58 & 34,876 & 8,507 & 6,324 & 930 & 4,096 & 1,658 & 4,563 & 15,184 & 145 & 4,431 & 19,687 & 11,193 & 7,367 & 9,564 & 5,104 & 16,351 & 27,524 & 177,503 \\
\hline 59 & 35,642 & 9,042 & 7,686 & 934 & 4,496 & 1,720 & 4,395 & 15,352 & 163 & 4,627 & 20,301 & 12,299 & 7,894 & 9,798 & 5,302 & 17,285 & 31,594 & 188,527 \\
\hline 1960 & 37,026 & 9,099 & 7,798 & 861 & 4,514 & 1,883 & 4,484 & 15,670 & 163 & 4,627 & 20,740 & 13,646 & 8,194 & 9,963 & 5,876 & 18,059 & 34,775 & 197,379 \\
\hline 61 & 35,052 & 11,459 & 7,895 & 870 & 4,843 & 2,083 & 3,914 & 18,279 & 177 & 5,974 & 23,652 & 13,150 & 8,869 & 10,274 & 6,287 & 19,014 & 35,924 & 207,715 \\
\hline 62 & 38,740 & 11,370 & 8,643 & 826 & 5,196 & 1,751 & 3,507 & 17,206 & 192 & 5,037 & 23,496 & 12,442 & 7,543 & 10,292 & 3,119 & 19,477 & 38,388 & 207,224 \\
\hline 63 & 34,160 & 11,049 & 8,836 & 840 & 5,575 & 1,654 & 3,029 & 15,360 & 222 & 3,807 & 22,279 & 12,023 & 6,457 & 9,949 & 3,761 & 19,650 & 37,592 & 196,241 \\
\hline 64 & 38,677 & 11,496 & 7,726 & 861 & 5,919 & 1,188 & 3,216 & 16,544 & 251 & 3,807 & 23,195 & 11,785 & 7,619 & 10,212 & 3,667 & 20,777 & 38,770 & 205,710 \\
\hline 1965 & 37,563 & 11,423 & 8,583 & 905 & 6,572 & 613 & 3,196 & 19,027 & 251 & 4,334 & 24,318 & 12,197 & 7,327 & 10,377 & 3,355 & 21,813 & 40,695 & 212,550 \\
\hline 66 & 40,179 & 11,938 & 8,370 & 806 & 7,165 & 764 & 2,828 & 17,388 & 251 & 4,919 & 24,142 & 10,471 & 6,128 & 10,386 & 3,417 & 22,691 & 39,336 & 211,180 \\
\hline
\end{tabular}


Table A1 (continued)

\begin{tabular}{|c|c|c|c|c|c|c|c|c|c|c|c|c|c|c|c|c|c|c|}
\hline & $\begin{array}{l}\text { Food } \\
\text { crops }\end{array}$ & $\begin{array}{l}\text { Animal } \\
\text { husbandry }\end{array}$ & $\begin{array}{l}\text { Farm } \\
\text { cash } \\
\text { crops }\end{array}$ & $\begin{array}{l}\text { Estate } \\
\text { crops }\end{array}$ & Fisheries & Forestry & Mining & Manufacturing & Utilities & Construction & Trade & $\begin{array}{l}\text { Transport, } \\
\text { communications }\end{array}$ & $\begin{array}{l}\text { Financial } \\
\text { services }\end{array}$ & Housing & $\begin{array}{l}\text { Public } \\
\text { administration }\end{array}$ & $\begin{array}{l}\text { Other } \\
\text { services }\end{array}$ & Oil, Gas & Total \\
\hline 67 & 36,985 & 10,380 & 8,314 & 803 & 7,038 & 1,440 & 2,804 & 19,160 & 325 & 4,275 & 24,134 & 9,101 & 5,881 & 10,265 & 3,771 & 21,168 & 42,792 & 208,638 \\
\hline 68 & 41,953 & 9,814 & 8,419 & 818 & 6,910 & 3,705 & 3,532 & 21,659 & 340 & 5,154 & 26,447 & 9,436 & 6,241 & 10,724 & 3,543 & 22,134 & 51,002 & 231,831 \\
\hline 69 & 41,662 & 10,885 & 9,251 & 887 & 7,240 & 4,477 & 3,829 & 23,070 & 444 & 7,028 & 28,186 & 9,321 & 7,141 & 11,032 & 6,403 & 23,008 & 62,851 & 256,715 \\
\hline 1970 & 46,232 & 10,954 & 9,184 & 939 & 7,324 & 6,369 & 4,547 & 30,198 & 444 & 8,785 & 32,991 & 9,964 & 8,413 & 11,751 & 6,635 & 24,644 & 72,270 & 291,644 \\
\hline 71 & 47,188 & 9,405 & 8,795 & 1,030 & 7,420 & 7,925 & 4,887 & 30,124 & 444 & 10,542 & 33,292 & 11,182 & 9,230 & 11,920 & 7,568 & 24,983 & 75,534 & 301,470 \\
\hline 72 & 45,963 & 10,709 & 9,521 & 1,075 & 7,565 & 9,527 & 5,579 & 34,848 & 447 & 13,001 & 36,769 & 12,053 & 10,914 & 12,420 & 9,599 & 25,950 & 91,762 & 337,703 \\
\hline 73 & 52,416 & 10,869 & 9,014 & 1,062 & 7,617 & 14,287 & 6,410 & 41,302 & 491 & 14,536 & 42,834 & 12,686 & 12,171 & 13,223 & 11,582 & 27,773 & 113,331 & 391,604 \\
\hline 74 & 54,051 & 10,574 & 9,053 & 1,211 & 7,967 & 12,003 & 7,839 & 42,349 & 565 & 16,768 & 43,444 & 12,449 & 11,935 & 13,328 & 13,995 & 28,413 & 116,379 & 402,321 \\
\hline 1975 & 53,832 & 10,968 & 9,234 & 1,268 & 8,288 & 9,256 & 7,476 & 45,566 & 592 & 17,991 & 44,189 & 12,381 & 12,352 & 13,450 & 16,222 & 29,363 & 110,617 & 403,044 \\
\hline 76 & 54,645 & 11,779 & 10,241 & 1,326 & 8,841 & 13,118 & 8,025 & 48,313 & 643 & 18,331 & 47,841 & 13,336 & 13,141 & 13,898 & 18,263 & 31,124 & 127,659 & 440,522 \\
\hline 77 & 55,522 & 12,194 & 10,076 & 1,432 & 9,371 & 12,688 & 8,759 & 53,052 & 657 & 21,349 & 50,245 & 15,235 & 14,269 & 14,305 & 19,222 & 32,993 & 142,762 & 474,130 \\
\hline 78 & 61,241 & 12,205 & 10,536 & 1,498 & 9,823 & 14,933 & 8,327 & 56,903 & 736 & 23,476 & 54,214 & 17,190 & 16,015 & 14,910 & 21,883 & 35,433 & 138,452 & 497,776 \\
\hline 79 & 61,990 & 12,335 & 12,199 & 1,591 & 10,424 & 14,048 & 9,589 & 64,986 & 857 & 24,055 & 59,412 & 19,044 & 17,110 & 15,411 & 27,701 & 37,913 & 134,693 & 523,357 \\
\hline 1980 & 68,434 & 13,132 & 12,210 & 1,670 & 11,028 & 15,443 & 10,302 & 76,338 & 933 & 26,274 & 67,218 & 21,109 & 19,934 & 16,296 & 34,821 & 40,727 & 133,778 & 569,647 \\
\hline 81 & 74,995 & 13,472 & 12,562 & 1,732 & 11,414 & 13,275 & 10,249 & 84,095 & 1,076 & 29,599 & 72,320 & 23,732 & 21,626 & 16,924 & 38,108 & 42,789 & 135,828 & 603,796 \\
\hline 82 & 74,030 & 13,098 & 11,466 & 1,955 & 11,909 & 12,816 & 11,339 & 85,120 & 1,263 & 31,144 & 72,556 & 24,572 & 22,229 & 16,976 & 36,067 & 43,725 & 112,171 & 582,435 \\
\hline 83 & 79,378 & 12,496 & 12,508 & 2,045 & 13,203 & 14,418 & 8,859 & 86,992 & 1,350 & 33,063 & 76,909 & 26,856 & 23,176 & 17,443 & 41,542 & 45,549 & 105,440 & 601,227 \\
\hline 84 & 83,849 & 13,463 & 12,804 & 2,428 & 13,560 & 12,970 & 8,231 & 106,176 & 1,394 & 31,600 & 77,649 & 29,117 & 27,799 & 17,858 & 43,616 & 48,423 & 113,007 & 643,944 \\
\hline 1985 & 86,041 & 14,506 & 14,038 & 2,784 & 14,508 & 12,337 & 8,536 & 118,058 & 1,553 & 32,422 & 80,622 & 29,404 & 29,678 & 18,225 & 46,950 & 51,062 & 101,318 & 662,041 \\
\hline 86 & 88,202 & 14,699 & 14,064 & 3,062 & 15,336 & 12,888 & 9,451 & 129,025 & 1,849 & 33,148 & 87,019 & 30,593 & 34,226 & 18,847 & 49,911 & 53,950 & 106,375 & 702,645 \\
\hline 87 & 89,127 & 15,035 & 14,678 & 3,077 & 15,927 & 14,036 & 10,109 & 142,713 & 2,128 & 34,543 & 92,956 & 32,363 & 35,957 & 19,653 & 53,576 & 57,057 & 106,252 & 739,186 \\
\hline 88 & 93,137 & 15,754 & 15,451 & 3,144 & 16,847 & 14,690 & 10,595 & 159,828 & 2,361 & 37,824 & 100,936 & 34,152 & 36,870 & 20,455 & 57,693 & 61,187 & 102,567 & 783,491 \\
\hline 89 & 97,014 & 17,019 & 20,077 & $\leftarrow$ & 17,764 & 15,058 & 12,478 & 177,860 & 2,681 & 42,835 & 112,288 & 37,830 & 44,166 & 24,046 & 61,074 & 65,171 & 107,665 & 855,027 \\
\hline 1990 & 98,233 & 18,192 & 22,006 & $\leftarrow$ & 18,371 & 15,290 & 15,028 & 199,105 & 3,201 & 50,083 & 124,260 & 41,312 & 52,113 & 28,397 & 63,865 & 70,185 & 112,711 & 932,354 \\
\hline 91 & 98,101 & 19,828 & 24,053 & $\leftarrow$ & 19,690 & 15,568 & 18,814 & 220,151 & 3,472 & 57,520 & 102,250 & 44,815 & 58,938 & 32,415 & 65,840 & 75,820 & 123,696 & 980,971 \\
\hline 92 & 105,106 & 21,158 & 25,687 & $\leftarrow$ & 20,723 & 15,824 & 22,916 & 242,560 & 3,780 & 64,681 & 149,579 & 48,343 & 65,687 & 32,974 & 67,789 & 82,108 & 119,424 & $1,088,339$ \\
\hline 93 & 104,416 & 22,163 & 27,318 & $\leftarrow$ & 21,826 & 16,033 & 26,068 & 270,159 & 4,200 & 74,054 & 163,917 & 51,990 & 72,246 & 33,533 & 69,161 & 89,714 & 119,547 & $1,166,346$ \\
\hline 94 & 102,185 & 23,052 & 28,702 & $\leftarrow$ & 22,939 & 16,118 & 29,695 & 303,555 & 4,727 & 85,056 & 174,995 & 56,328 & 82,250 & 34,888 & 70,067 & 97,819 & 122,644 & $1,255,019$ \\
\hline 1995 & 107,208 & 24,260 & 30,037 & $\leftarrow$ & 24,029 & 16,125 & 36,667 & 336,566 & 5,479 & 96,044 & 188,876 & 61,113 & 93,412 & 36,812 & 70,972 & 106,354 & 122,645 & $1,356,598$ \\
\hline 96 & 109,470 & 25,488 & 31,379 & $\leftarrow$ & 25,326 & 16,484 & 42,561 & 375,581 & 6,226 & 108,300 & 204,005 & 66,419 & 97,427 & 38,965 & 71,872 & 115,724 & 124,418 & $1,459,647$ \\
\hline 97 & 106,352 & 26,738 & 31,808 & $\leftarrow$ & 26,792 & 18,392 & 45,493 & 395,304 & 6,996 & 116,269 & 216,238 & 71,073 & 102,942 & 40,902 & 72,729 & 123,663 & 123,679 & $1,525,369$ \\
\hline 98 & 107,972 & 23,082 & 34,045 & $\leftarrow$ & 26,410 & 16,963 & 43,982 & 350,095 & 7,179 & 73,882 & 176,292 & 60,323 & 67,952 & 32,774 & 67,404 & 112,395 & 120,681 & $1,321,432$ \\
\hline 99 & 110,659 & 24,429 & 32,431 & $\leftarrow$ & 28,963 & 16,085 & 45,836 & 363,824 & 7,804 & 72,484 & 174,830 & 59,869 & 61,188 & 30,805 & 68,522 & 113,871 & 114,460 & $1,326,061$ \\
\hline 2000 & 112,356 & 25,231 & 32,491 & $\leftarrow$ & 30,411 & 16,343 & 50,536 & 385,598 & 8,394 & 76,573 & 184,970 & 65,012 & 64,314 & 31,872 & 69,460 & 119,054 & 117,156 & $1,389,770$ \\
\hline 01 & 112,580 & 27,629 & 35,015 & $\leftarrow$ & 31,912 & 16,738 & 56,794 & 398,324 & 9,058 & 80,080 & 192,541 & 70,276 & 68,991 & 34,142 & 70,200 & 125,622 & 111,451 & $1,441,353$ \\
\hline 02 & 114,982 & 29,431 & 37,073 & $\leftarrow$ & 33,003 & 17,125 & 61,801 & 419,388 & 9,868 & 84,470 & 199,649 & 76,173 & 72,322 & 37,321 & 70,482 & 134,141 & 108,131 & $1,505,359$ \\
\hline 03 & 119,165 & 30,647 & 38,694 & $\leftarrow$ & 34,668 & 17,214 & 64,517 & 441,755 & 10,349 & 89,622 & 210,653 & 85,458 & 76,434 & 40,512 & 71,148 & 143,249 & 103,087 & $1,577,171$ \\
\hline 04 & 122,612 & 31,673 & 38,849 & $\leftarrow$ & 36,596 & 17,434 & 61,464 & 469,952 & 10,898 & 96,334 & 222,290 & 96,897 & 81,420 & 44,112 & 72,324 & 155,026 & 98,636 & $1,656,517$ \\
\hline 2005 & 125,802 & 32,347 & 39,811 & $\leftarrow$ & 38,746 & 17,177 & 68,328 & 491,561 & 11,584 & 103,598 & 241,887 & 109,262 & 85,570 & 47,715 & 73,700 & 166,834 & 96,895 & $1,750,815$ \\
\hline 06 & 129,549 & 33,430 & 41,318 & $\leftarrow$ & 41,419 & 16,687 & 72,176 & 514,100 & 12,251 & 112,234 & 257,847 & 124,976 & 87,697 & 51,755 & 76,618 & 179,383 & 95,853 & $1,847,293$ \\
\hline 07 & 133,889 & 34,221 & 43,136 & $\leftarrow$ & 43,653 & 16,504 & 76,665 & 538,085 & 13,517 & 121,901 & 280,486 & 142,327 & 94,722 & 55,819 & 80,778 & 192,634 & 94,757 & $1,963,092$ \\
\hline 08 & 141,800 & 35,553 & 44,793 & $\leftarrow$ & 45,753 & 16,440 & 77,111 & 557,766 & 14,994 & 130,816 & 301,498 & 166,077 & 101,934 & 60,775 & 84,378 & 207,229 & 95,190 & $2,082,105$ \\
\hline
\end{tabular}

Sources: These estimates are based on Indonesia's new national accounts for 2000-08, following the latest 2000 revision (see Van der Eng, 2005), and updates. The 2000-08 output data were linked to official

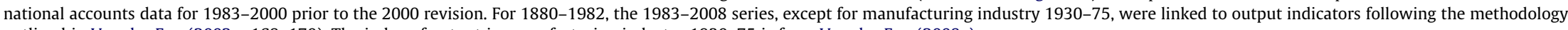
outlined in Van der Eng (2002a: 168-170). The index of output in manufacturing industry 1930-75 is from Van der Eng (2008a). 
Table A2

Key data for the Calculation of TFP, 1880-2008.

\begin{tabular}{|c|c|c|c|c|}
\hline & \multicolumn{2}{|l|}{ (Billion $2000 \mathrm{Rp}$ ) } & \multirow[t]{2}{*}{ Employment (1000) } & \multirow[t]{2}{*}{ Educational attainment per person (years) } \\
\hline & GDP (at market prices) & Non-residential capital stock & & \\
\hline 1880 & 44,638 & 26,758 & 12,483 & 0.04 \\
\hline 81 & 47,470 & 28,446 & 12,606 & 0.04 \\
\hline 82 & 45,868 & 27,495 & 12,732 & 0.04 \\
\hline 83 & 45,367 & 27,200 & 12,859 & 0.04 \\
\hline 84 & 49,338 & 29,568 & 12,988 & 0.05 \\
\hline 1885 & 50,206 & 30,086 & 13,119 & 0.05 \\
\hline 86 & 50,241 & 30,112 & 13,252 & 0.05 \\
\hline 87 & 51,003 & 30,571 & 13,386 & 0.05 \\
\hline 88 & 51,171 & 30,676 & 13,523 & 0.06 \\
\hline 89 & 51,094 & 30,633 & 13,661 & 0.06 \\
\hline 1890 & 50,423 & 30,236 & 13,802 & 0.06 \\
\hline 91 & 51,638 & 30,965 & 13,944 & 0.06 \\
\hline 92 & 53,905 & 32,315 & 14,089 & 0.07 \\
\hline 93 & 55,010 & 32,971 & 14,236 & 0.07 \\
\hline 94 & 55,935 & 33,531 & 14,385 & 0.07 \\
\hline 1895 & 56,446 & 33,836 & 14,536 & 0.07 \\
\hline 96 & 56,849 & 34,082 & 14,690 & 0.08 \\
\hline 97 & 57,848 & 34,677 & 14,846 & 0.08 \\
\hline 98 & 58,394 & 35,011 & 15,005 & 0.08 \\
\hline 99 & 61,768 & 37,024 & 15,166 & 0.08 \\
\hline 1900 & 64,089 & 38,414 & 15,330 & 0.09 \\
\hline 01 & 63,234 & 37,903 & 15,490 & 0.09 \\
\hline 02 & 62,041 & 37,198 & 15,652 & 0.09 \\
\hline 03 & 65,657 & 39,357 & 15,817 & 0.10 \\
\hline 04 & 66,614 & 39,927 & 15,985 & 0.10 \\
\hline 1905 & 67,519 & 40,471 & 16,155 & 0.11 \\
\hline 06 & 69,420 & 40,759 & 16,331 & 0.11 \\
\hline 07 & 71,217 & 45,079 & 16,509 & 0.12 \\
\hline 08 & 71,251 & 52,811 & 16,690 & 0.12 \\
\hline 09 & 74,787 & 54,020 & 16,874 & 0.13 \\
\hline 1910 & 79,407 & 58,178 & 17,061 & 0.14 \\
\hline 11 & 83,242 & 60,598 & 17,241 & 0.15 \\
\hline 12 & 84,650 & 64,717 & 17,425 & 0.16 \\
\hline 13 & 88,559 & 69,940 & 17,611 & 0.17 \\
\hline 14 & 88,572 & 78,268 & 17,801 & 0.18 \\
\hline 1915 & 89,785 & 82,397 & 17,993 & 0.19 \\
\hline 16 & 90,572 & 86,515 & 18,173 & 0.20 \\
\hline 17 & 90,841 & 89,999 & 18,357 & 0.22 \\
\hline 18 & 92,683 & 92,434 & 18,545 & 0.23 \\
\hline 19 & 101,480 & 103,697 & 18,736 & 0.25 \\
\hline 1920 & 98,644 & 110,449 & 18,931 & 0.26 \\
\hline 21 & 98,861 & 121,580 & 19,132 & 0.28 \\
\hline 22 & 101,657 & 125,744 & 19,338 & 0.29 \\
\hline 23 & 103,709 & 129,119 & 19,539 & 0.31 \\
\hline 24 & 109,100 & 132,381 & 19,744 & 0.33 \\
\hline 1925 & 111,230 & 135,180 & 19,953 & 0.35 \\
\hline 26 & 117,834 & 140,766 & 20,165 & 0.37 \\
\hline 27 & 125,299 & 147,594 & 20,382 & 0.39 \\
\hline 28 & 129,901 & 158,907 & 20,404 & 0.42 \\
\hline 29 & 132,837 & 171,899 & 20,606 & 0.44 \\
\hline 1930 & 134,540 & 181,478 & 20,813 & 0.47 \\
\hline 31 & 125,759 & 184,971 & 21,091 & 0.49 \\
\hline 32 & 120,471 & 186,564 & 21,374 & 0.51 \\
\hline 33 & 121,224 & 186,484 & 21,662 & 0.53 \\
\hline 34 & 122,697 & 183,100 & 21,955 & 0.56 \\
\hline 1935 & 125,612 & 185,254 & 22,259 & 0.58 \\
\hline 36 & 133,020 & 186,361 & 22,572 & 0.60 \\
\hline 37 & 148,348 & 194,363 & 22,907 & 0.62 \\
\hline 38 & 146,989 & 202,936 & 23,252 & 0.64 \\
\hline 39 & 147,733 & 208,005 & 23,604 & 0.66 \\
\hline 1940 & 161,510 & 209,669 & 23,649 & 0.68 \\
\hline 41 & 168,099 & 215,555 & 24,088 & 0.71 \\
\hline 1949 & 117,313 & & 27,912 & 0.82 \\
\hline 1950 & 131,918 & 197,227 & 28,434 & 0.82 \\
\hline 51 & 142,075 & 206,233 & 28,956 & 0.83 \\
\hline 52 & 150,943 & 216,064 & 29,336 & 0.87 \\
\hline 53 & 155,912 & 224,614 & 29,403 & 0.91 \\
\hline 54 & 167,394 & 231,088 & 29,418 & 0.96 \\
\hline
\end{tabular}


Table A2 (continued)

\begin{tabular}{|c|c|c|c|c|}
\hline & \multicolumn{2}{|l|}{ (Billion $2000 \mathrm{Rp}$ ) } & \multirow[t]{2}{*}{ Employment (1000) } & \multirow[t]{2}{*}{ Educational attainment per person (years) } \\
\hline & GDP (at market prices) & Non-residential capital stock & & \\
\hline 1955 & 168,073 & 234,524 & 29,672 & 1.02 \\
\hline 56 & 172,558 & 236,563 & 30,056 & 1.07 \\
\hline 57 & 179,884 & 236,526 & 30,498 & 1.12 \\
\hline 58 & 177,503 & 236,647 & 31,052 & 1.16 \\
\hline 59 & 188,527 & 236,880 & 31,612 & 1.22 \\
\hline 1960 & 197,379 & 236,200 & 32,279 & 1.29 \\
\hline 61 & 207,715 & 240,232 & 32,709 & 1.36 \\
\hline 62 & 207,224 & 242,919 & 33,456 & 1.44 \\
\hline 63 & 196,241 & 242,680 & 34,225 & 1.52 \\
\hline 64 & 205,710 & 243,710 & 35,016 & 1.61 \\
\hline 1965 & 212,550 & 244,667 & 35,834 & 1.70 \\
\hline 66 & 211,180 & 247,468 & 36,672 & 1.78 \\
\hline 67 & 208,638 & 247,348 & 37,534 & 1.87 \\
\hline 68 & 231,831 & 251,258 & 38,430 & 1.96 \\
\hline 69 & 256,715 & 255,740 & 39,318 & 2.05 \\
\hline 1970 & 291,644 & 262,058 & 40,279 & 2.13 \\
\hline 71 & 301,470 & 275,712 & 41,261 & 2.21 \\
\hline 72 & 337,703 & 290,177 & 42,377 & 2.28 \\
\hline 73 & 391,604 & 303,745 & 43,523 & 2.33 \\
\hline 74 & 402,321 & 319,589 & 44,486 & 2.39 \\
\hline 1975 & 403,044 & 336,419 & 45,726 & 2.45 \\
\hline 76 & 440,522 & 352,660 & 47,000 & 2.52 \\
\hline 77 & 474,130 & 372,794 & 48,310 & 2.61 \\
\hline 78 & 497,776 & 397,818 & 49,657 & 2.70 \\
\hline 79 & 523,357 & 422,625 & 51,041 & 2.81 \\
\hline 1980 & 569,647 & 454,004 & 52,421 & 2.92 \\
\hline 81 & 603,796 & 488,300 & 54,294 & 3.05 \\
\hline 82 & 582,435 & 530,502 & 56,238 & 3.18 \\
\hline 83 & 601,227 & 585,570 & 58,254 & 3.32 \\
\hline 84 & 643,944 & 629,553 & 60,347 & 3.45 \\
\hline 1985 & 662,041 & 675,301 & 62,519 & 3.59 \\
\hline 86 & 702,645 & 729,203 & 64,774 & 3.74 \\
\hline 87 & 739,186 & 789,056 & 67,114 & 3.89 \\
\hline 88 & 783,491 & 861,528 & 69,543 & 4.03 \\
\hline 89 & 855,027 & 950,963 & 72,064 & 4.16 \\
\hline 1990 & 932,354 & $1,070,366$ & 74,396 & 4.29 \\
\hline 91 & 980,971 & $1,206,918$ & 76,137 & 4.42 \\
\hline 92 & $1,088,339$ & $1,345,078$ & 77,928 & 4.55 \\
\hline 93 & $1,166,346$ & $1,491,960$ & 79,768 & 4.69 \\
\hline 94 & $1,255,019$ & $1,665,386$ & 81,660 & 4.82 \\
\hline 1995 & $1,356,598$ & $1,870,199$ & 83,311 & 4.96 \\
\hline 96 & $1,459,647$ & $2,101,456$ & 85,003 & 5.10 \\
\hline 97 & $1,525,369$ & $2,342,446$ & 86,738 & 5.24 \\
\hline 98 & $1,321,432$ & $2,432,763$ & 88,517 & 5.38 \\
\hline 99 & $1,326,061$ & $2,480,786$ & 90,342 & 5.52 \\
\hline 2000 & $1,389,770$ & $2,550,631$ & 92,528 & 5.66 \\
\hline 01 & $1,441,353$ & $2,629,659$ & 93,818 & 5.78 \\
\hline 02 & $1,505,359$ & $2,706,739$ & 95,738 & 5.88 \\
\hline 03 & $1,577,171$ & $2,783,430$ & 97,689 & 5.97 \\
\hline 04 & $1,656,517$ & $2,894,323$ & 99,665 & 6.06 \\
\hline 2005 & $1,750,815$ & $3,033,085$ & 101,652 & 6.14 \\
\hline 06 & $1,847,293$ & $3,168,553$ & 103,635 & 6.23 \\
\hline 07 & $1,963,092$ & $3,331,091$ & 105,632 & 6.32 \\
\hline 08 & $2,082,105$ & $3,530,096$ & 107,637 & 6.39 \\
\hline
\end{tabular}

Sources: See Table A1 and main text.

\section{References}

Abramovitz, M., David, P., 2001. Two Centuries of American Macroeconomic Growth from Exploitation of Resource Abundance to Knowledge-Driven Development. SIEPR Discussion Paper No. 01-05. Stanford Institute for Economic Policy Research, Stanford.

Aswicahyono, H., Hill, H., 2002. Perspiration versus inspiration in Asian industrialisation: Indonesia before the crisis. Journal of Development Studies 38 (3), 138-163.

Baier, S.L., Dwyer, G.P., Tamura, R., 2006. How important are capital and total factor productivity for economic growth? Economic Inquiry 44 (1), 23-49. Booth, A., 1998. The Indonesian Economy in the Nineteenth and Twentieth Centuries: A History of Missed Opportunities. Macmillan, Basingstoke.

Bosworth, B.P., Collins, S.M., Chen, Y.C., 1995. Accounting for Differences in Economic Growth, Brookings Discussion Papers in International Economics, No. 115. The Brookings Institution, Washington, DC. 
BPS, 1987. Penduduk Indonesia: Hasil Survei Penduduk antar Sensus 1985, [Indonesia's Population: Results of the 1985 Inter-Census Population Survey]. Biro Pusat Statistik, Jakarta.

BPS, 1992. Penduduk Indonesia: Hasil Sensus Penduduk 1990, Seri S2 [Indonesia's Population: Results of the 1990 Population Census]. Biro Pusat Statistik, Jakarta. BPS, 1996a. Sistem Neraca Sosial Ekonomi Indonesia 1993, [The System of Socio-Economic Accounts of Indonesia in 1993]. Biro Pusat Statistik, Jakarta.

BPS, 1996b. Penduduk Indonesia: Hasil Survei Penduduk antar Sensus 1995, Seri S2 [Indonesia's Population: Results of the 1995 Inter-Census Population Survey]. Biro Pusat Statistik, Jakarta.

BPS, 1999. Sistem Neraca Sosial Ekonomi Indonesia 1998, [The System of Socio-Economic Accounts of Indonesia in 1998]. Badan Pusat Statistik, Jakarta. BPS, 2002. Penduduk Indonesia: Hasil Sensus Penduduk Tahun 2000, [Indonesia's Population: Results of the 2000 Population Census]. Badan Pusat Statistik, Jakarta. BPS, 2003. Sistem Neraca Sosial Ekonomi Indonesia 2000, [The System of Socio-Economic Accounts of Indonesia in 2000]. Badan Pusat Statistik, Jakarta.

BPS, 2005. Sistem Neraca Sosial Ekonomi Indonesia Tahun 2003, [The System of Socio-Economic Accounts of Indonesia in the year 2003]. Badan Pusat Statistik, Jakarta.

BPS, 2006. Penduduk Indonesia: Hasil Survei Penduduk antar Sensus 2005, Seri S1 [Indonesia's Population: Results of the 2005 Inter-Census Population Survey]. Badan Pusat Statistik, Jakarta.

BPS, 2008. Sistem Neraca Sosial Ekonomi Finansial Indonesia 2005, [The System of Socio-Economic-Financial Accounts of Indonesia 2005]. Badan Pusat Statistik, Jakarta.

CBS, 1948. De Nationale Rekeningen voor Nederlandsch-Indië, 1938, [National Accounts for the Netherlands Indies, 1938]. Statistische en Econometrische Onderzoekingen 4, 61-75.

CEI3, 1977. Changing Economy in Indonesia, vol. 3: Expenditure on Fixed Assets. Nijhoff, The Hague.

Chen, E.K.Y., 1997. The total factor productivity debate: determinants of economic growth in East Asia. Asian-Pacific Economic Literature 11 (1), 18-38.

Collins, S.M., Bosworth, B.P., 1996. Economic growth in East Asia: accumulation versus assimilation. Brookings Papers on Economic Activity 2, 135-203.

Crafts, N.F.R., 2004. Quantifying the contribution of technological change to economic growth in different eras: a review of the evidence. In: Heikkinen, S., van Zanden, J.L. (Eds.), Exploring Economic Growth. Aksant, Amsterdam, pp. 205-226.

Dick, H. et al, 2002. Emergence of a National Economy: An Economic History of Indonesia 1800-2000. University of Hawai'i Press, Honolulu.

Drysdale, P., Huang, Y., 1997. Technological catch-up and productivity growth in East Asia. Economic Record 73, $201-211$.

Felipe, J., 1999. Total factor productivity growth in East Asia: a critical survey. Journal of Development Studies 34 (4), 1-41.

Firdausy, C.M., 2005. Productivity Performance in Developing Countries, Country Case Studies: Indonesia. Report for the United Nations Industrial Development Organization (UNIDO). Available from: <http://www.unido.org/file-storage/download/?file_id=60412>.

Hayashi, M., 2005. SMEs, Subcontracting and Economic Development in Indonesia: With Reference to Japan's Experience. Japan International Cooperation Publishing, Tokyo.

Hill, H., 1999. The Indonesian Economy since 1966: Southeast Asia's Emerging Giant. CUP, Cambridge.

Hugo, G.J. et al, 1987. The Demographic Dimension in Indonesian Development. Oxford, UP, Singapore.

Ikhsan-Modjo, M., 2006. Total Factor Productivity in Indonesian Manufacturing: A Stochastic Frontier Approach. ABERU Discussion Paper No.28. Caulfield East: Department of Economics, Monash University.

Kawai, H., 1994. International comparative analysis of economic growth. The Developing Economies 32 (4), 373-397.

Keppy, P., 2006. Sporen van Vernieling: Oorlogsschade, Roof en Rechtsherstel in Indonesië 1940-1957 [Signs of Destruction: War Damage, Theft and Rehabilitation in Indonesia, 1940-1957]. Boom, Amsterdam.

Keuning, S.J., Saleh, K., 2000. SAM and SESAME in Indonesia: Results, Usage and Institutionalization' in Studies in Methods, Series F, No. 75/vol. 2, Handbook of National Accounting: Household Accounting. Experience in Concepts and Compilation, vol. 2, Household Satellite Extensions. (United Nations, Department of Economic and Social Affairs, Statistics Division, New York) pp. 355-397.

Krugman, P., 1994. The Myth of Asia's Miracle. Foreign Affairs 73 (6), 62-78.

Lindauer, D.L., Roemer, M., 1994. Legacies and opportunities. In: Lindauer, D.L., Roemer, M. (Eds.), Asia and Africa: Legacies and Opportunities in Development. ICS Press, San Francisco, pp. 1-24.

Maddison, A., 1987. Growth and slowdown in advanced capitalist economies: techniques of quantitative assessment. Journal of Economic Literature 25, 649-698.

Maddison, A., 1995. Standardised estimates of fixed capital stock: a six country comparison. In: Maddison, A. (Ed.), Explaining the Economic Performance of Nations: Essays in Time and Space. Edward Elgar, Aldershot, pp. 137-166.

Maddison, A., 2003. The World Economy: Historical Statistics. OECD, Paris.

Nehru, V., Dhareshwar, A., 1993. A new database of physical capital stock: sources, methodology and results. Revista de Análisis Económico 8, 37-59.

NPB, 1957. A study of the Indonesian economic development scheme. Ekonomi dan Keuangan Indonesia 10, 600-642.

Polak, J.J., 1943. The National Income of the Netherlands Indies, 1921-1939. Netherlands and Netherlands-Indies Council of the Institute of Pacific Relations, New York. (Reprinted in CEI5 (1979) Changing Economy in Indonesia. vol. 5: National Income. Nijhoff, The Hague, pp. 25-102).

Prados de la Escosura, L., Rosés, J.R., 2003. Wages and labor income. In: Mokyr, Joel (Ed.), The Oxford Encyclopedia of Economic History, vol. 4. Oxford, UP, New York, pp. 48-52.

Prados de la Escosura, L., Rosés, J.R., 2007. The Sources of Long-Run Growth in Spain 1850-2000. Working Papers in Economic History WP07-02. Department of Economic History and Institutions, Universidad Carlos III de Madrid, Getafe.

Rodrik, D., 1998. TFPG controversies, institutions, and economic performance. In: Hayami, Y., Aoki, M. (Eds.), The Institutional Foundations of East Asian Economic Development. Macmillan, London, pp. 79-101.

Saleh, K., Jammal, Y., 2002. Towards Income Accounts for Indonesia. Report No. 14, STAT Project. Badan Pusat Statistik, Jakarta.

Sarel, M., 1997. Growth and Productivity in ASEAN Countries. IMF Working Paper No. WP/97/97. International Monetary Fund, Washington, DC.

Sigit, H., 2000a. Telaah Data Ketenagakerjaan di Indonesia' [Analysis of employment data in Indonesia]. Laporan No. 5, STAT Project. Badan Pusat Statistik, Jakarta.

Sigit, H., 2000b. Earning Data in Indonesia: A Review of Existing Sources. Report No. 10, STAT Project. Badan Pusat Statistik, Jakarta.

Sigit, H., 2004. Indonesia. In: Oguchi, Noriyoshi (Ed.), Total Factor Productivity Growth: Survey Report. Asian Productivity Organization, Tokyo, pp. 98-133.

Timmer, M., 1999. Indonesia's ascent on the technology ladder: capital stock and total factor productivity in Indonesian manufacturing, 1975-95. Bulletin of Indonesian Economic Studies 35 (1), 75-89.

Van der Eng, P., 1992. The real domestic product of Indonesia, 1880-1989. Explorations in Economic History $28,343-373$.

Van der Eng, P., 1999. Some obscurities in Indonesia's new national accounts. Bulletin of Indonesian Economic Studies 35 (2), $91-106$.

Van der Eng, P., 2002a. Indonesia's growth performance in the 20th century. In: Maddison, A., Prasada Rao, D.S., Shepherd, W. (Eds.), The Asian Economies in the Twentieth Century. Edward Elgar, Cheltenham, pp. 143-179.

Van der Eng, P., 2002b. Bridging a gap: a reconstruction of population patterns in Indonesia, 1930-1961. Asian Studies Review 26, 487-509.

Van der Eng, P., 2004. Business in Indonesia: old problems and new challenges. In: Basri, Mohammad Chatib, van der Eng, Pierre (Eds.), Business in Indonesia: New Challenges, Old Problems. Institute of Southeast Asian Studies, Singapore, pp. 1-20.

Van der Eng, P., 2005. Indonesia's new national accounts. Bulletin of Indonesian Economic Studies 41 (2), $253-262$.

Van der Eng, P., 2008. Labour-Intensive Industrialisation in Indonesia, 1930-1975: Output Trends and Government Policies. Working Papers in Trade and Development No. 2008/20. Division of Economics, Research School of Pacific and Asian Studies, Australian National University, Canberra.

Van der Eng, P., 2009. Capital formation and capital stock in Indonesia, 1950-2008. Bulletin of Indonesian Economic Studies 45, 345-371.

Vial, V., 2006. New estimates of total factor productivity growth in Indonesian manufacturing. Bulletin of Indonesian Economic Studies 42 (3), 357-369.

Weerasinghe, P.N., Fane, G., 2005. Accounting for discrepancies among estimates of TFP growth in East Asia. Economic Papers 24 (3), 280-293.

Young, A., 1994. Accumulation, exports and growth in the high performing Asian economies: a comment. Carnegie-Rochester Conference Series on Public Policy 40, 237-250. 